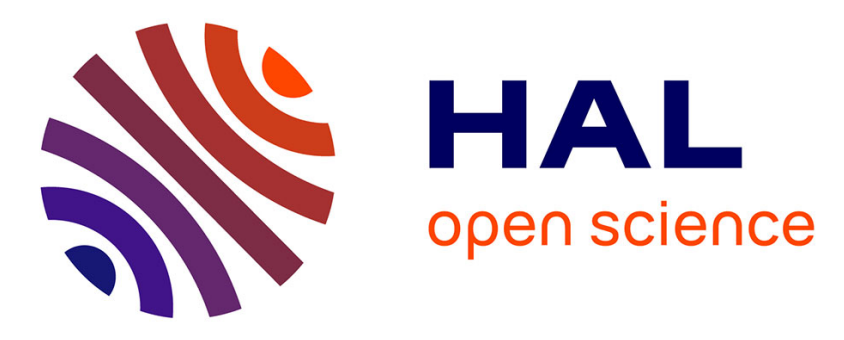

\title{
The plant sterol guggulsterone attenuates inflammation and immune dysfunction in murine models of inflammatory bowel disease
}

Andrea Mencarelli, Barbara Renga, Giuseppe Palladino, Eleonora Distrutti, Stefano Fiorucci

\section{To cite this version:}

Andrea Mencarelli, Barbara Renga, Giuseppe Palladino, Eleonora Distrutti, Stefano Fiorucci. The plant sterol guggulsterone attenuates inflammation and immune dysfunction in murine models of inflammatory bowel disease. Biochemical Pharmacology, 2009, 78 (9), pp.1214. 10.1016/j.bcp.2009.06.026 . hal-00519081

\section{HAL Id: hal-00519081 \\ https://hal.science/hal-00519081}

Submitted on 18 Sep 2010

HAL is a multi-disciplinary open access archive for the deposit and dissemination of scientific research documents, whether they are published or not. The documents may come from teaching and research institutions in France or abroad, or from public or private research centers.
L'archive ouverte pluridisciplinaire HAL, est destinée au dépôt et à la diffusion de documents scientifiques de niveau recherche, publiés ou non, émanant des établissements d'enseignement et de recherche français ou étrangers, des laboratoires publics ou privés. 


\section{Accepted Manuscript}

Title: The plant sterol guggulsterone attenuates inflammation and immune dysfunction in murine models of inflammatory bowel disease

Authors: Andrea Mencarelli, Barbara Renga, Giuseppe Palladino, Eleonora Distrutti, Stefano Fiorucci

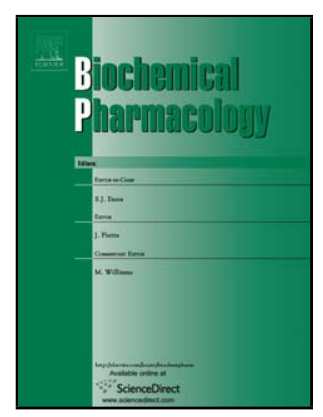

PII: S0006-2952(09)00496-1

DOI: doi:10.1016/j.bcp.2009.06.026

Reference: BCP 10236

To appear in: $\quad B C P$

Received date: $\quad$ 15-5-2009

Revised date: $\quad$ 12-6-2009

Accepted date: $\quad$ 16-6-2009

Please cite this article as: Mencarelli A, Renga B, Palladino G, Distrutti E, Fiorucci $\mathrm{S}$, The plant sterol guggulsterone attenuates inflammation and immune dysfunction in murine models of inflammatory bowel disease, Biochemical Pharmacology (2008), doi:10.1016/j.bcp.2009.06.026

This is a PDF file of an unedited manuscript that has been accepted for publication. As a service to our customers we are providing this early version of the manuscript. The manuscript will undergo copyediting, typesetting, and review of the resulting proof before it is published in its final form. Please note that during the production process errors may be discovered which could affect the content, and all legal disclaimers that apply to the journal pertain. 
The plant sterol guggulsterone attenuates inflammation and immune dysfunction in murine models of inflammatory bowel disease

\section{Short title}

Guggulsterone and intestinal inflammation

Andrea Mencarelli', Barbara Renga', Giuseppe Palladino', Eleonora Distrutti2, and Stefano Fioruccil

'Dipartimento di Medicina Clinica e Sperimentale, Università di Perugia, Via E. dal Pozzo, 06122 Perugia, Italy and ${ }^{2}$ Azienda Ospedaliera S.M. della Misericordia,

Perugia, Italy

\section{Disclosure \\ Non conflict of interest}

\section{Author contribution}

Andrea Mencarelli, has carried out animal studies, ELISA kit and flow cytometry and the manuscript writing

Barbara Renga carried out quantitative RT-PCR experiments

Giuseppe Palladino carried out histological analysis

Stefano Fiorucci and Eleonora Distrutti: designed the study and participate to the manuscript writing

Correspondence should be addressed to Andrea Mencarelli, PhD.

Dipartimento di Medicina Clinica e Sperimentale

Via E. dal Pozzo

06122 Perugia

Italy

Email: fiorucci@unipg.it

Fax: 0039-075-5855819 


\section{Abstract}

Inflammatory bowel diseases (IBD) are chronic inflammatory and relapsing diseases of the gut that may manifest as either Crohn's disease (CD) or ulcerative colitis (UC). CD and UC are immunologically different diseases characterized by exacerbated Th1 and Th2 response. T-cell resistance against apoptosis contributes to inappropriate T-cell accumulation and the perpetuation of chronic mucosal inflammation. In the present study we have investigated the effect exerted by guggulsterone (GS) a plant derived steroid isolated from the gum resin of the Commiphora mukul tree, in two models of intestinal inflammation induced in mice by trinitro-benzene sulfonic acid (TNBS) and oxazolone. We provided evidence that E-GS protects mice against development of sign and symptoms of colon inflammation. E-GS effectively attenuated the severity of wasting disease and the fecal score and colon inflammation as assessed by measuring the macroscopic- and microscopic-damage scores. Administration Z-GS failed to ameliorate colon inflammation in TNBS-induced colitis and had a partial effect in oxazolone-induced colitis. In vitro, mechanistic studies carried out using CD4+ cells isolated from the intestinal lamina propria demonstrate that GS effectively regulates the function of effector $T$ cells by modulation cell signaling activation pathway caused by CD3/CD28. The net biological effects resulting from exposure to GS includes attenuation of generation of Interleukin-2 and -4 and interferon$Y$ as well as $T$ cell proliferation. In conclusion, $G S$ as an anti-inflammatory compound with the capacity to prevent and ameliorate T-cell-induced colitis. These data ground the use of GS, a natural cholesterol-lowering agent, in the treatment of chronic inflammatory diseases. 


\section{Introduction}

Inflammatory bowel disease (IBD) is a chronic progressive and destructive disorder of the gastrointestinal tract that may manifest as either Crohn's disease (CD) or ulcerative colitis (UC) [1-4]. There is circumstantial evidence to link the pathogenesis of IBD to a dysfunctional interaction between bacterial microflora of the gut and the mucosal immune system. The normal state of immunologic tolerance to microbial antigens in the gastrointestinal tract is disturbed either by the presence of a dysregulated mucosal effector T cell population that overreacts to usual microbial antigens or, alternatively, by the presence of a defective mucosal Treg cell population that under-reacts to usual microbial antigens such that even normal effector T cells are not properly modulated [5].

$C D$ and UC are immunologically different diseases. Indeed, CD bears all the stigmata of an exaggerated CD4+ Thelper (Th) 1 cell response, characterized by high interferon (IFN)- $Y$ and interleukin (IL)-12, whereas, in UC, the mucosal immune response is dominated by the production of IL-5 and IL-13 [6,7]. Several factors have been implicated in the unrelenting mucosal inflammation of IBD, prominent among them being the presence of a persistently elevated number of activated T cells in the mucosa of CD and UC patients. These T cells display various defects of proliferation and apoptosis, and these abnormalities are credited with directly contributing to the pathogenesis of IBD [8]. Thus, therapeutic approaches inhibiting $T$ cell proliferation such as steroids, azathioprine/6-MP, calcineurin inhibitors and anti-IL2 and IL-2 receptor or drugs inducing T cell apoptosis such as tumor necrosis factor(TNF)-a and CD3 monoclonal antibodies and anti-cytokines 
strategies (IL-6 and IL-12) responsible of inhibition of apoptotic pathway in T cells, are effective in treating $C D$ and $U C$ [9-14].

Guggulsterone (GS) [4,17(20)-pregnadiene-3,16-dione] is a plant derived steroid isolated from the gum resin of the Commiphora mukul tree, termed guggulipid, extensively used in the Ayurvedic medicine to treat conditions associated with inflammation such as hyperlipidemia, obesity, and arthritis [15-18]. The active substances in guggulipid are the pregnane plant sterols cisguggulsterone (E-GS) and trans-guggulsterone (Z-GS). GS has anticancer potential as indicated by its ability to suppress the proliferation of a wide variety of human tumor cell lines. GS as also been shown to induce apoptosis and reverse chemoresistance [20-23]. The activity of GS has been suggested to be mediated by antagonism of metabolic nuclear receptors [24]. The two stereoisomers of the plant sterol, bind to the farnesoid-x-receptor, the mineralocorticoid receptor, the androgen, the glucocorticoid and progesterone receptors at nanomolar concetrations. However, in cell-based functional cotransfection assays, GSS behave as an antagonist for all these receptors [24]. Agonist activity has been demonstrated for the pregnane-x-receptor and was also demonstrated with estrogen receptor alfa, however the potency is very low [24]. GS exerts potent anti-inflammatory effects by suppressing the activation of the transcription factor NF-kappa B in response to different pro-infiammatory mediators including TNFa and IL-1 $\beta[23-25]$.

Here, we report that GS was effective in reducing inflammation in two rodent models of colitis in mice. We demonstrated that GS reduced colonic inflammation and suppressed the mediators of adaptive immunity. Mechanistic 
1

2

studies carried out using CD4+ cells derived from intestinal lamina propria demonstrate that GS effectively regulates the function of effector T cells. 


\section{Methods and Materials}

\subsection{Animals:}

BALB/C and SCID mice, 8-10 weeks of age, were obtained from Harlan Nossan (Udine, Italy). Mice were housed under controlled temperatures $\left(22^{\circ} \mathrm{C}\right)$ and photoperiods (12:12-hour light/dark cycle). The mice were allowed unrestricted access to standard mouse chow and tap water. They were allowed to acclimate to these conditions for at least 5 days before inclusion in an experiment. Protocols were approved by the University of Perugia Animal Care Committee.

\subsection{Reagents}

Purified myeloperoxidase (MPO), tri-methylbenzidine, dichlorofluorescin diacetate, trinitro-benzene sulfonic acid, oxazolone and Z-guggulsterone were obtained from Sigma-Aldrich (Milan, Italy). E-guggulsterone were purchased from Steraloids (Newport, R.I.)

\subsection{Experimental Procedures}

\subsubsection{Induction of Colitis}

Mice were lightly anesthetized by intraperitoneal injection of $100 \mu \mathrm{\mu l}$ ketamine/xylazine solution (Mix $0.6 \mathrm{ml}$ of ketamine, $100 \mathrm{mg} / \mathrm{ml}, 0.4 \mathrm{ml}$ of xylazine, $20 \mathrm{mg} / \mathrm{ml}$ and $4 \mathrm{ml}$ of saline) per $10 \mathrm{~g}$ body weight and then administered intrarectally (i.r.) with the haptenating agents: TNBS (1 mg/mouse) or oxazolone ( $1.5 \mathrm{mg} / \mathrm{mouse}$ ) dissolved in ethanol 50\%, via a 3.5 French (F) catheter equipped with a 1-ml syringe. The catheter was advanced into the rectum for $4 \mathrm{~cm}$ and then the haptenating agent was administered in a total volume of $150 \mu$. To ensure distribution of the agent within the entire colon and cecum, mice were held in a vertical position for 30 seconds. Control mice were administered by an ethanol solution using the same technique. GSs were dissolved each day in 100 mM DMSO, diluted in methylcellulose $1 \%$ and administrated intraperitoneally at the final volume of $200 \mu \mathrm{L} /$ mouse. TNBS/oxazolone group mice received the vehicle alone (1\% methylcellulose in a final volume of $200 \mathrm{\mu L} /$ mouse) every day. In a further set of experiments nive were administered prednisolone 10 
$\mathrm{mg} / \mathrm{kg} /$ day i.p. In all protocol studies, mice were monitored for the appearance of diarrhea, loss of body weight, and overall mortality. Five days after TNBS/oxazolone administration, surviving mice were sacrificed, colons were removed and immediately snap-frozen on liquid nitrogen and stored at $-80^{\circ} \mathrm{C}$ until use. The macroscopic appearance was analyzed considering the presence of indurations, edema, thickness and evidence of mucosal hemorrhage. Grading was performed in a blinded fashion.

\subsubsection{Histological Grading of Colitis}

For histological examination, tissues were fixed in $10 \%$ buffered formalin phosphate, embedded in paraffin, sectioned, and stained with Hematoxylin and eosin (H\&E). Histology images were captured by a digital camera (SPOT-2; Diagnostic Instruments Inc, Burroughs, MI) and analyzed by specific software (Delta Sistemi, Rome, Italy).The degree of inflammation on microscopic cross sections was graded semiquantitatively from 0 to 4 (0, no signs of inflammation; 1, very low level; 2, low level of leukocyte infiltration; 3, high level of leukocyte infiltration, high vascular density, and thickening of the colon wall; and 4, transmural infiltration, loss of goblet cells, high vascular density, and thickening of the colon wall). Grading was performed in a blinded fashion.

\subsubsection{Real-Time PCR}

Quantization of the expression level of selected genes was performed by quantitative real-time PCR (qRT-PCR). Total RNA were obtained from small colon pieces $(50 \mathrm{mg}$ ) and isolated with TRIzol reagent (Invitrogen, Milan, Italy), incubated with DNase I and reverse-transcribed with Superscript II (Invitrogen) according to manufacturer specifications. For real-time PCR, $100 \mathrm{ng}$ of template was used in a $25-\mu$ reaction containing a $0.3 \mu \mathrm{M}$ concentration of each primer and $12.5 \mu \mathrm{l}$ of 2x SYBR Green PCR Master Mix (Bio-Rad Laboratories, Hercules, CA). All reactions were performed in triplicate using the following cycling conditions: 2 min at $95^{\circ} \mathrm{C}$, followed by 50 cycles of $95^{\circ} \mathrm{C}$ for $10 \mathrm{~s}$ and $60^{\circ} \mathrm{C}$ for $30 \mathrm{~s}$ using an iCycler $\mathrm{QQ}$ instrument (Bio-Rad Laboratories). The mean value of the replicates for each sample was calculated and expressed as cycle threshold $\left(\mathrm{C}_{T}\right)$. The amount of gene 
expression was then calculated as the difference $\left(\Delta \mathrm{C}_{\mathrm{T}}\right)$ between the $\mathrm{C}_{\mathrm{T}}$ value of the sample for the target gene and the mean $C_{T}$ value of that sample for the endogenous control (GAPDH). Relative expression was calculated as the difference $\left(\Delta \Delta \mathrm{C}_{\mathrm{T}}\right)$ between the $\Delta \mathrm{C}_{\mathrm{T}}$ values of the test and control samples for each target gene. The relative level of expression was measured as $2^{-\Delta \Delta C T}$. All PCR primers were designed using the software PRIMER3-OUTPUT using published sequence data obtained from the NCBI database.

Mouse primers were as follows:

mGAPDH: CTGAGTATGTCGTGGAGTCTAC and GTTGGTGGTGCAGGATGCATTG;

mIL-2: AACTCCCCAGGATGCTCAC and CGCAGAGGTCCAAGTTCATC;

mIL-4: CCTCACAGCAACGAAGAACA and ATCGAAAAGCCCGAAAGAGT;

mIL-6: CCGGAGAGGAGACTTCACAG and TCCACGATTTCCCAGAGAAC;

mIL-10: GCTGGACAACATACTGCTAACC and CTGGGGCATCACTTCTACCA;

mINFY: GCGTCATTGAATCACACCTG and GACCTGTGGGTTGTTGACTC;

mTNFa: ACGGCATGGATCTCAAAGAC and GTGGGTGAGGAGCACGTAGT mTGFB: TGGCTTCAGCTCCACAGAGA and TGGTTGTAGAGGGCAAGGAC.

\subsection{Purification of colon lamina propria CD4+ cells}

Colonic lamina propria T cells were isolated from colon mice $(\mathrm{N}=10)$ as previously described [26]. In brief, after excision of all visible lymphoid follicles, colons were washed in calcium- and magnesium-free HBSS and treated with 1 mM EDTA in PBS for $20 \mathrm{~min}$ to remove the epithelium. The tissue was then digested with type IV collagenase (Sigma) for $20 \mathrm{~min}$ in a shaking incubator at $37^{\circ} \mathrm{C}$; this step was repeated twice. The released cells were then layered on a $40 \%-100 \%$ Percoll gradient (Pharmacia, Upsala, Sweden) and spun at 1,800 rpm to obtain the leukocyte-enriched population at the $40 \%-100 \%$ interface.

An enriched lamina propria CD4+ T-cell population was obtained by negative selection with magnetic beads (magnetic-activated cell sorting [MACS]; Miltenyi 
Biotech, Auburn, CA). The purity of the cell preparations (>95\%) was determined by flow cytometry (Coulter Epics XL; Beckman Coulter, Fullerton, CA). LAMINA PROPRIA CD4+ T cells were then suspended in complete medium (RPMI 1640, 10\% heat-inactivated fetal calf serum, $3 \mathrm{mmol} / \mathrm{L} \mathrm{I}$-glutamine, $10 \mathrm{mmol} / \mathrm{L}$ HEPES buffer, $10 \mathrm{\mu g} / \mathrm{mL}$ penicillin, $100 \mathrm{U} / \mathrm{mL}$ streptomycin, and $0.05 \mathrm{mmol} / \mathrm{L}$ 2-mercaptoethanol) and cultured at a concentration of $2 \times 10^{6}$ cells $/ \mathrm{ml}$.

\subsubsection{Cytokine production and $T$ cell proliferation}

Lamina propria CD4+ T cells were obtained from mice 5 days after TNBS or oxazolone administration. The cells were placed for 48 hours into uncoated culture wells (to measure production by unstimulated cells) or into wells containing immobilized murine anti-CD3є $5 \mathrm{\mu g} / \mathrm{mL}$ MAb (clone 145-2C11; Pharmingen) and 5 $\mu \mathrm{g} / \mathrm{mL}$ soluble anti-CD28 antibody (clone 37.51; Pharmingen) alone or in combination with GS $(10 \mu \mathrm{M})$. At the end of incubation culture supernatants were harvested and assayed for cytokine concentration by specific enzymelinked immunosorbent assay kits from Biosource (Invitrogen, Milan, Italy). For assessment of cell proliferation cells were pulsed for $6 \mathrm{~h}$ with $\left[\mathrm{H}^{3}\right]$ thymidine $(0.5$ $\mathrm{\mu Ci} /$ well), harvested on glass fiber filters and radioactivity counted (in cpm) by a liquid scintillation system.

\subsection{Measure of pJNKS, pP38 and PAKT(ser473) activity}

Lamina propria CD4+ T cells were obtained from mice sacrificed 5 days after TNBS or oxazolone administration. The cells $\left(2 \times 10^{6} / \mathrm{mL}\right)$ placed for into uncoated culture wells (naive cells) or into wells containing immobilized murine anti-CD3є 5 $\mathrm{\mu g} / \mathrm{mL} \mathrm{mAb}$ (clone 145-2C11; Pharmingen) and $5 \mathrm{\mu g} / \mathrm{mL}$ soluble anti-CD28 antibody (clone 37.51; Pharmingen) alone or in combination with GS (100-10 $\mu \mathrm{M})$. GS, were prepared freshly in $10 \mathrm{mM}$ DMSO and subsequentially serial dilution were made in complete medium. Cells were harvested at pre-specified time points and JNKs1/2 (pThr183/Tyr185), p38MAPK(pTyr180/182) and PAKT(ser473) determination by specific enzyme-linked immune-sorbent assay kits from Biosource (Invitrogen, Milan, Italy). The data were represented $\mu \mathrm{g}$ of protein. 


\subsection{Measurement of apoptosis and reactive oxygen species by T cells}

The percentage of apoptotic nuclei of lamina propria CD4+ T cells incubated with GSs was assessed by using the propidium iodide (PI) technique [27] using a flow cytometer (Coulter Epics XL).

Generation of intracellular reactive oxygen species (ROS) was measured by loading the cells with the fluorogenic probe dichlorofluorescin diacetate (DCFHDA). DCFH-DA is deacetylated in cells, where it can react quantitatively with intracellular radicals, mainly $\mathrm{H}_{2} \mathrm{O}_{2}$, to be converted to its fluorescent product, 2', 7'dichlorofluorescein, which is retained in the cells and thus provides an index of cell cytosolic oxidation. At the end of the incubation periods, $20 \mu \mathrm{mol} / \mathrm{L}$ of DCFH-DA was added for 30 minutes at $37^{\circ} \mathrm{C}$, and analyzed by using a flow cytometer. The results were expressed as delta of increase of mean fluorescence intensity compared to cells treated with anti-CD3 anti-CD28 alone.

\subsection{Flow cytometric measurement of mitochondrial membrane potential}

Integrity of mitochondrial membrane was assessed by measuring the mitochondrial membrane potential $\left(\Delta \psi_{m}\right)$ by flow cytometry using the aggregate-forming lipophilic cation $\mathrm{JC}^{-1}$ as a substrate. After eliminating small (ie, noncellular) debris, 50,000 events were collected for each analysis. Results are expressed either as the mean aggregate fluorescence alone (red).

\subsection{Cytochrome $C$ release and caspase activity}

Migration of cytochome $c$ into the cytosol is a meaure of mitochondrial membrane injury. To obtain cytosolic fractions, lamina propria-derived CD+ cells were washed twice in ice-cold PBS, resuspended in cold buffer (1.28 M NaCl, 50.0 $\mathrm{mM} \mathrm{KCl}, \quad 50.0 \mathrm{mM} \mathrm{MgSO}{ }_{4}, 13.0 \mathrm{mM} \mathrm{CaCl}, 0.5 \mathrm{M}$ HEPES, $1.0 \mathrm{mM}$ phenylmethylsulfonyl fluoride, $10 \%$ vol $2.5 \mathrm{M}$ sucrose, $10.0 \mathrm{mM}$ 1,4-dithiothreitol, 1.0 $\mathrm{mM}$ reduced glutathione, and $1 \%$ glycerol) and homogenized mechanically. The total cellular extract was centrifuged at $2000 \mathrm{rpm}$ for 3 minutes at $4^{\circ} \mathrm{C}$ and the cytosolic supernatant recovered and analyzed for the presence of cytochrome $C$ by Cytochrome c Oxidase Assay Kit (Sigma-Aldrich; Milan, Italy). 
Caspase 3, 8 and 9 activity was measured by a specific caspase fluorometric protease assay according to the manufacturer's instructions (ApoAlert; Clontech, Palo Alto, CA).

\subsection{Statistical analysis}

All values are expressed as the mean \pm SE of $n$ mice per group. Comparisons of more than 2 groups were made with a 1-way analysis of variance with post hoc Tukey tests. Differences were considered statistically significant if $P$ was $<0.05$. 


\section{Results}

\subsection{Anti-Inflammatory effects of E-GS in a Th1-mdediated model of colitis}

Murine TNBS colitis is thought to be a model of Thl-mediated disease with dense infiltrations of lymphocytes/macrophages in the lamina propria and thickening of the colon wall [28-31]. In order to assess whether GS could exert immunemodulatory activity, mice administered TNBS were treated with E-GS and Z-GS at the dose of $30 \mathrm{mg} / \mathrm{kg} / \mathrm{day}$ for 5 days. The results of these experiments demonstrates that administration of E-GS effectively attenuates colitis development as measured by assessing local and systemic signs of inflammation. Thus E-GS effectively protected against development of the wasting disease (Figure ID) ( $n=8-10, P<0.05)$, and appearance and severity of diarrhea measured as a fecal- score, but also attenuated the macroscopic- and microscopic-damage scores (Figure $1 \mathrm{~A}-\mathrm{B}-\mathrm{C}-\mathrm{E})$ ( $\mathrm{n}=8-10, \mathrm{P}<0.05$ versus TNBS group). In contrast to E-GS, its stereoisomer was significantly less effective. Figure IF illustrates a representative image of histophatological analysis. Compared with colons of mice given vehicle alone, colons obtained frommice administered TNBS show an extensive cellular infiltrate, submucosal edema, and large areas of epithelial erosion that were reduced by E-GS treatment. Furthermore, the E-GS treatment $(30 \mathrm{mg} / \mathrm{kg})$ significantly attenuated the TNBS-induced increase of expression colonic expression of inflammatory and immune mediators including INFY, IL-2, IL-6, TNFa and TGFB (Figure 2) ( $n=5, P<0.05)$. The effect exerted by E-GS was dose-dependent and was lost in animal administered E-GS at the dose of 5 and $15 \mathrm{mg} / \mathrm{kg} / \mathrm{day}$ (supplementary figure 1, on line).

\subsection{Anti-Inflammatory effects of E-GS in Th2 model of IBD}

We have then assessed whether protection exerted by GS against colitis development was maintained in a model of Th2 mediated disease. For this purpose we used the oxazolone model of colitis, a model of colon inflammation that shows similarities with human UC [31-33]. Administering oxazolone-treated mice with E-GS $(30 \mathrm{mg} / \mathrm{kg})$ effectively protected against the development of wasting disease and attenuated colon inflammation as measured by assessing 
the macroscopic and microscopic scores and neutrophil infiltration (figure 3A-BC-D-E) $(\mathrm{n}=8-10, P<0.05)$. In contrast to the E-GS, Z-GS $(30 \mathrm{mg} / \mathrm{kg})$ exerted no protective effect also in the oxazolone model (Figure 2 A-B-C-D-E) ( $n=8-10, P<$ 0.05). In addition, E-GS treatment effectively reduced the expression of proinflammatory genes IL-2, IL-4, IL-6 and TNFa in the colon of oxazolone treated mice oxazolone $(n=5, P<0.05)$.

\subsection{E-GS and Innate immunity model of IBD}

Because E-GS administration reduced immune-cellular infiltration in the lamina propria of balb/c mice, experiments were carried out to further define the immune compartment mediating E-GS actions in vivo. For this purpose, we tested E-GS (30 $\mathrm{mg} / \mathrm{kg}$ ) in T and B cell-deficient SCID mice, in which innate immune cells provide important triggers for TNBS colitis [34]. SCID mice developed TNBS colitis as illustrated in Figure 3, but, in this experimental model, E-GS was unable to revert local and systemic signs of inflammation caused by TNBS administration. These findings suggest that E-GS, at least partially, acts directly on cells of adaptive immunity in vivo.

\subsection{E-GS attenuates activation of lamina propria CD4+ cells}

Because results from SCID mice suggest that GSs might act on cells of adaptive immunity we have then carried out a series of ex vivo experiments to investigate the functional effects of GSS on lamina propria-derived T cells obtained from mice treated with TNBS or oxazolone. Exposure to these chemical agents results in a T cell polarization and generation of $C D 4+$ cell clones with a Th1 or Th2 profile. Exposure of TNBS-primed CD4+ cells to E-GS $(10 \mu \mathrm{M})$ attenuated IL-2 and INFY production caused by anti-CD3 and anti-CD28. In addition, E-GS effectively inhibited IL-2 and IL-4 production by oxazolone-primed cells exposed to the same mixture of activating antibodies (Figure $3 A, B, D, E)(n=3, P<0.05$ versus CD3CD28 group). Furthermore, E-GS, effectively inhibited proliferation of lamina propria derived CD4+ T cells in both models (Figure 9C,F) ( $n=3, P<0.05$ versus CD3CD28 group). In all these experimental settings Z-GS was less effective than its stereoisomer. 


\subsection{In Vitro Effect of GS in lamina propria CD4+ cells signalling}

The principal intracellular pathway involved in T-cells activation by $T$ cell receptor crosslinking includes JNKs, p38MAPK and Akt/PKB [35-37]. Thus we have investigated whether GS (100-10 $\mu \mathrm{M})$ modulates the phosphorylation of $\mathrm{p}$ (Thr183/Tyr 185) JNKs, $\mathrm{p}$ (ser473)AKT and $\mathrm{p}$ (Tyr 180/182)p38MAPK induced by CD3CD28 stimulation of lamina propria-derived CD4+ cells obtained from mice treated with TNBS. Figure 5A illustrate that CD3-CD28 induced a 3-5 folds increase of pJNKs. A robust induction of this pattern of phosphorylation was found in cell exposed to $G S$ sterosiomers $(100 \mu M)(n=3, P<0.05)$. Subsequent to dysregulation of JNKs we also observed a p38MAPK hyperphosphorilation that increased progressively until 3 hours ( $n=3, P<0.05$ versus CD3-CD28 group). GS-stereisomers at lower doses $(10 \mu \mathrm{M})$ had no effect on pJNKs/p38MAPK levels. In addition we found that $p$ (ser473)AKT phosphorylation was markedly inhibited by exposure to Z-GS, 10 and $100 \mu \mathrm{M}$, (Figure 5) ( $\mathrm{n}=3, \mathrm{P}<0.05$ versus CD3-CD28 group). The total quantity of JNKs, AKT and P38MAPK did not change in the indicated time frame (data not shown).

\subsection{GS drives lamina propria CD4+ $T$ cells to apoptosis.}

We have next investigated whether in addition to its immune-modulatory activity GSs drive lamina propria derived CD4+ cells to apoptosis. For this purpose lamina propria-derived CD4+ cells stimulated with CD3/CD28 agonistic antibodies were treated with two different doses of GS, 10 and $100 \mu \mathrm{M}$ for a different amount of time (6-12-24 hours). As shown in Figure 6A, both GS stereoisomers at dose of $100 \mu \mathrm{M}$ caused a time-dependent apoptosis of CD4+ cells (figure 6A) ( $n=5, P<$ 0.05 versus CD3-CD28 group), with E-GS being more effective in comparison with $Z$-GS ( $n=6, P<0.05)$. Again insight on the mechanism mediating the pro-apoptotic activity of GSs we have then measured a number of intracellular mediator of apoptosis in TNBS-primed CD4+ cells exposed to CD3/CD28 agonistic in the presence of GS stereoisomers. As illustrated in Figure 6, exposure to these stereoisomers significantly increased ROI generation and mitochondrial dysfunction as measured by assessing mitochondrial membrane potential $\left(\Delta \Psi_{\mathrm{m}}\right)$ 
and the transition of $\mathrm{Cy}+\mathrm{C}$ from the mitochondria to the cytosol. Experiments shown in Figure 6 demonstrate that while GS at low dose has no effect on $\Delta \psi_{m}$ in lamina propria CD4+ cells stimulated with CD3-CD28, both stereoisomers caused $\Delta \Psi_{\mathrm{m}}$ collapse. This effect associated with transition of $\mathrm{Cyt} C$ from mitochondria to cytosol ( $n=6, P<0.05$ versus CD3-CD28 group). Again E-GS was more efficacious than $\mathrm{Z}-\mathrm{GS}$ ( $\mathrm{n}=6, \mathrm{P}<0.05$ versus CD3-CD28 group). In addition exposure to GS, high concentrations, resulted in a robust induction of caspase-3, 8 and 9 activity (Figure 6B,C) (n=6, $P<0.05$ versus CD3-CD28 group). These data indicated GS activates both the extrinsic and intrinsic apoptosis pathway but E-GS was more efficacious inducing mitochondrial damage. The pro-apototic effect of GS on CD4+ cells was reversed by exposing lamina-propria derived $T$ cells to SP600125 (1 MM) a JNKs inhibitor ( $n=6, P<0.05$ versus CD3-CD28 plus GSs).

\subsection{Comparative effects of E-GS and prednisolone in TNBS induced colitis.}

Steroid are commonly used in the treatment of IBD, we have therefore compared the effect of E-GS with that of a commonly used steroid, prednisolone, in the prevention of development of colitis induced by TNBS. For this purpose, we have used a dose of prednisolone of $10 \mathrm{mg} / \mathrm{kg}$ previously shown to be effective in protecting mice from colitis induced by TNBS. As shown in figure 7, protection exerted by E-GS $(30 \mathrm{mg} / \mathrm{kg})$ was similar to that seen in animals administered prednisolone at the dose of $10 \mathrm{mg} / \mathrm{kg} \quad(\mathrm{P}<0.05$ versus TNBS alone for both treatments). The two treatments exerted the same protective activity against systemic and local signs of inflammation caused by TNBS. 


\section{Discussion}

Identification of active principles and their molecular targets from traditional medicine is an important opportunity for modern medicine. The gum resin from Commiphora mukul has been used for centuries in Ayurvedic medicine to treat a number of inflammatory disorders. GS has been identified as one of the major active components of this gum resin [20-25]. Modulation of gene expression by GS leads to inhibition of cell proliferation, induction of apoptosis, suppression of invasion and abrogation of angiogenesis [20-25]. Evidence has been provided to suggest that GS is also effective in attenuating tumor cell growth and metastasis [38].

A previous work [39] has demonstrated that GS exerts a protective effect in a model of colon inflammation induced in mice by oral administration of dextran sulfate sodium (DSS). Mechanistic studies carried out to explain the protective effects have shown that GS inhibits ICAM-1 gene expression induced by bacterial endotoxin and IL-1 $\beta$-induced through a mechanism that involvesinhibition of NFkappaB transcriptional activity, IkappaB phosphorylation/degradation and NFkappaB DNA binding activity in intestinal epithelial cells line [39]. However, since it is generally believed that DSS is directly toxic to gut epithelial cells and affects the integrity of the mucosal barrier this model is not suitable for investigating the role of effector T cells, the main mechanism involved in tissue destruction in IBD. The fact that T- and B-cell-deficient C.B-17scid or Rag1-1- mice still develop intestinal inflammation when challenged with DSS support the notion that the adaptive immune system plays a minor role (at least in the acute phase) in this model [40].

Intestinal inflammation induced by TNBS and oxazolone are two immunologically mediated models of IBD. In the TNBS model, inflammation and a T-cell-mediated immune dysfunction develop in response to the exposure to hapten-modified autologous proteins/luminal antigens [31]. Using this model we provided evidence that E-GS protects mice against development of sign and symptoms of colon inflammation. Thus administering mice with E-GS, 15 and 30 $\mathrm{mg} / \mathrm{kg}$, effectively attenuated the severity of wasting disease and the fecal 
score and colon inflammation as assessed by measuring the macroscopic- and microscopic-damage scores. By striking contrast, administration Z-GS at the dose of $30 \mathrm{mg} / \mathrm{kg}$ failed to ameliorate colon inflammation. Furthermore, while E-GS treatment significantly attenuated the TNBS-induced increase of expression of INFY, IL-2, IL-6, TNFa and TGFB mRNAs in the colon, these effects were not reproduced by Z-GS.

Rectal administration of oxazolone allows to study the contribution of the Th2-dependent immune response to intestinal inflammation. E-GS was effective in reducing inflammation induced by oxazolone and reduced systemic and local signs of inflammation including the severity of wasting disease and the colon macroscopic and microscopic scores. This effect was accompanied by a robust attenuation of neutrophil infiltration and tissue expression of proinflammatory cytokines. Again, Z-GS was less effective than its stereoisomer in treating this condition.

To define the immune compartment mediating the effect of GS in vivo, we have then tested the effect of GS in a model of colitis induced by TNBS administration to $T$ and $B$ cell depleted SCID mice. Of outstanding interest we found that, in comparison to control mice, E-GS at the dose of $30 \mathrm{mg} / \mathrm{kg}$ was only partially effective in reducing inflammation (weight loss score, stool consistency score and mucosal damage score) induced by TNBS administration to SCID mice, strongly suggesting that $\mathrm{T}$ (or B) cells could be a target for this agent.

$\mathrm{CD} 4^{+} \mathrm{T}$ lymphocytes mediate a key component of the intestinal mucosal immune defence against pathogens [10]. To gain insights on the mechanisms mediating the anti-inflammatory activity of GS we have therefore tested its effects on effector functions of CD4+ cells purified from the intestinal lamina propria. Results of these in vitro studies demonstrated that exposure to E-GS causes T cell apoptosis and inhibits T-cells proliferation induced by co-incubation with a mixture of anti-CD3 and anti-CD28 activating antibodies.

T cell receptor stimulation by anti-CD3 activates a family of mitogenactivated protein kinases (MAPKs), that are serine/threonine kinases, that include Jun $\mathrm{NH}_{2}$-terminal kinases (JNKs) and p38MAPK [36]. While $\mathrm{T}$ cell receptor activation by anti-CD3 agonist mAb drives $T$ cell to apoptosis, co-stimulation by 
CD28 agonistic antibody recruits phosphatidyl-inositol-3-kinase (PI3K) inducing the downstream phosphorylation of serine/threonine of AKt/PKB molecule, an event that leads to CD4+ cell activation [37]. Previous works [41-43] indicated that activation of JNKS1/2 and P38MAPK and inhibition of AKT/PBK were biomarkers of GS response in cancer cell lines. In the present study we have provided evidence that exposure of lamina propria-derived CD4+ cells to E-GS, resulted in a fine tuning of these phosphorylation/activating pathways. Thus while exposure to GS results in hyperphosphorylation of Thr183/Tyr185 of JNKs1/2 and Tyr180/182 of p38MAPK, p(ser473)AKT phosphorylation caused by CD3/CD28 was significantly inhibited. The net effects resulting from these biochemical changes induced by exposure of lamina propria CD4+ to GS could support the observed the induction of apoptosis. This effect was also associated with an increased of $\mathrm{ROI}$ generation, mitochondrial membrane depolarization and release of CytC from damaged mitochondria. Activation of the ERK pathway typically confers growth and survival responses, while p38 and JNKs may promote cell death so that the cellular fate in response to any stimulus is a function of the relative levels of activation of each MAPK [44]. The importance of the kinetics of JNKs activation in the induction of apoptosis in T cells is further underscored by the finding that transient JNKs activation by CD3/CD28 co-ligation does not lead to apoptosis whereas a prolonged activation induced by stress stimuli (UV, Yirradiation, anisomycin, $\mathrm{H}_{2} \mathrm{O}_{2}$ and TNFa), mediates the activation of both the extrinsic and intrinsic pathway of apoptosis [45-47]. A number of results suggest that GS targets mitochondria to trigger ROI generation, which is highly likely because JNKs1/2 activation and apoptosis induction by this agent are significantly attenuated by overexpression of intramitochondrial Mn-SOD $[41,48]$. Support to the role JNKs in this model of apoptosis were provided also by experiments with SP600125, a JNKs inhibitor. Thus exposure to this agent reverted apoptosis induced by GS-stereoisomers.

In addition to inhibition of JNKs, exposure of lamina propria-derived T cells to E-GS caused a robust inhibition of $p(s e r 473) A K T$ phosphorylation. In T cells Akt activation/phosphorylation requires stimulation of both TCR and CD28 [49]. There is considerable evidence that Akt is an important mediator of T cells survival, thus 
its inhibition might contribute to the anti-proliferative and pro-apopototic actibvities of GS in lamina propria-derived T cells [50]. CD28 costimulation and AKT activation is also important for IL-2 and IFN-Y generation by Th 1 polarized T cells, and therefore it might also contribute to attenuation of $T$ cell function, documented in this report $[51,52]$.

T helper cells derived form the lamina propria of mice exposed for 5 days to TNBS or oxazolone, develop a phenotype with a Th1 or Th2 profile. We have demonstrated ex vivo exposure of these cells to E-GS inhibited IL-2 and INFY production by CD4+ T cells obtained from TNBS treated mice, and IL-2 and IL-4 production by $\mathrm{CD} 4+\mathrm{T}$ cells obtained from oxazolone treated mice. In both cell subtypes exposure to GS inhibited cells proliferation.

Several of the biological effects exerted by GSs on T cells effector function require a concentration of these stero-isomers of approximately $10 \mu \mathrm{M}$. Despite the pharmacokinetic of GSs is only partially known, a study performed in rats has shown that $50 \mathrm{mg} / \mathrm{kg}$ bodyweight oral application of GSs resulted in peak plasma concentrations of $3.2 \mu \mathrm{M}$ [53]. Because we have administered GS systemically by intraperitoneal injection at the dose of $30 \mathrm{mg} / \mathrm{kg}$, it is likely that GS concentrations used for in vitro studies may reasonably match the plasma concentrations reached in our in vivo experiments.

Here we have compared the pharmacological effects of E-GS with that of prednisolone, a commonly used steroid (4). Steroid represent the front-line therapy of IBD, however their use associates with endocrine and metabolic side-effects that are dose-dependent and related to the length of treatment (4). Here we have provided evidence that in a pre-clinical model of IBD, E-GS gives approximately the same protection of a fairly high dose of prednisolone $(4,34,54,55)$. In contrast to steroids, side effects of GSs are uncommon, although it is reported that skin reaction develop in approximately $15 \%$ of patients taking a dose of 75-150 mg/day of the compound (56).

In summary, we have provided evidence that GSs exerts anti-inflammatory activities in mouse models of colitis by targeting, among other mechanisms, lamina propria T cells. On the light that therapeutic approaches inhibiting T cell proliferation such as glucocorticoids, azathioprine/6-MP and anti-TNF-a antibodies 
1

2

3

4

5

6

7

8

9

10

11

12

13

14

15

16

17

18

19

20

21

22

23

24

25

26

27

28

29

30

31

32

33

34

35

36

37

38

39

40

41

42

43

44

45

46

47

48

49

50

51

52

53

54

55

56

57

58

59

60

61

62

63

64

65

are effectively used to treat CD and UC, our results support the notion that GSs might be added to list of compounds that have utility in the treatment of IBD. 


\section{References}

1. Loftus EVJ. Clinical epidemiology of inflammatory bowel disease: incidence, prevalence, and environmental influences. Gastroenterology 2004; 126:1504-1517.

2. Strober W, Fuss I, Mannon PJ. The fundamental basis of inflammatory bowel disease. J Clin Invest 2007; 117: 514-521.

3. Kakazu T, Hara J, Matsumoto T, Nakamura S, Oshitani N, Arakawa T, et al. Type 1 T-helper cell predominance in granulomas of Crohn's disease, Am J Gastroenterology 1999; 94:2149-2155.

4. Velayos FS, Sandborn WJ. Positioning biologic therapy for Crohn's disease and ulcerative colitis. Curr Gastroenterol Rep. 2007;9:521-7.

5. Bouma G, Strober, W. The immunological and genetic basis of inflammatory bowel disease. Nat Rev Immunol. 2003; 3: 521-533.

6. Parronchi $P$, Romagnani $P$, Annunziato $F$, Sampognaro S, Becchio A, Giannarini $L$, et al. Type 1 T-helper cell predominance and interleukin-12 expression in the gut of patients with Crohn's disease. Am J Pathol. 1997; 150:823-832.

7. Xavier RJ, Podolsky DK. Unravelling the pathogenesis of inflammatory bowel disease. Nature 2007; 448:427-34.

8. Sturm A, de Souza HS, Fiocchi C. Mucosal T cell proliferation and apoptosis in inflammatory bowel disease. Curr Drug Targets. 2008; 5: 381-387.

9. Hanaver SB, Feagan BG, Lichtenstein GR, Mayer LF, Schreiber S, Colombel $\mathrm{JF}$, et al. Maintenance infliximab for Crohn's disease: the ACCENT I randomised trial. Lancet 2002; 359:1541-1549.

10. Mudter J, Neurath MF. Apoptosis of T cells and the control of inflammatory bowel disease: therapeutic implications. Gut 2006; 56: 293-303.

11. Mannon PJ, Fuss IJ, Mayer L, Elson CO, Sandborn WJ, Present D, et al. Antiinterleukin-12 antibody for active Crohn's disease. N Engl J Med 2004;351: 2069-2079. 
12. Ito H, Takazoe M, Fukuda Y, Hibi T, Kusugami K, Andoh A, et al. A pilot randomized trial of a human anti-interleukin-6 receptor monoclonal antibody in active Crohn's disease. Gastroenterology 2004; 126: 989-996.

13. Targan SR, Salzberg BA,Mayer L. A phase I-II study: multiple dose levels of visilizumab are well tolerated and produce rapid and sustained improvement in ulcerative colitis patients refractory to treatment with intravenous steroids (IVSR-UC). Gastroenterology 2005; 128:A-75.

14. Creed T, Norman M, Probert C, Harvey RF, Shaw IS, Smithson J, et al. Basiliximab (anti-CD25) in combination with steroids may be an effective new treatment for steroidresistant ulcerative colitis. Aliment Pharmacol Ther 2003; 18: 65-75.

15. Agarwal RC, Singh SP, Saran RK, Das SK, Sinha N, Asthana OP, et al. Clinical trial of gugulipid-a new hypolipidemic agent of plant origin in primary hyperlipidemia. Indian J Med Res 1986; 84:626.

16. Khanna D, Sethi G, Ahn KS, Pandey MK, Kunnumakkara AB, Sung B, et al. Natural products as a gold mine for arthritis treatment, Curr Opin Pharmacol 2007; 7:344.

17.Singh RB, Niaz MA, Ghosh S. Hypolipidemic and antioxidant effects of Commiphora mukul as an adjunct to dietary therapy in patients with hypercholesterolemia. Cardiovasc Drugs Ther 1994; 8: 659.

18. Urizar NL, Moore DD. GUGULIPID: a natural cholesterol-lowering agent. Annu Rev Nutr 2003; 23: 303.

19. Singh SV, Choi S, Zeng Y, Hahm ER, Xiao D. Guggulsterone-induced apoptosis in human prostate cancer cells is caused by reactive oxygen intermediate dependent activation of c-Jun NH2-terminal kinase. Cancer Res 2007; 67: 7439-49.

20. Shishodia S, Sethi G, Ahn KS, Aggarwal BB. Guggulsterone inhibits tumor cell proliferation, induces Sphase arrest, and promotes apoptosis through activation of c-Jun $\mathrm{N}$-terminal kinase, suppression of Akt pathway, and downregulation of antiapoptotic gene products. Biochem Pharmacol 2007; 74:118-130. 
21.Samudio I, Konopleva M, Safe S, McQueen T, Andreeff M. Guggulsterones induce apoptosis and differentiation in acute myeloid leukemia: identification of isomer-specific antileukemic activities of the pregnadienedione structure. Mol Cancer Ther 2005; 4:1982-92.

22.Singh SV, Zeng Y, Xiao D, Vogel VG, Nelson JB, Dhir R, et al. Caspasedependent apoptosis induction by guggulsterone, a constituent of Ayurvedic medicinal plant Commiphora mukul, in PC-3 human prostate cancer cells is mediated by Bax and Bak. Mol Cancer Ther 2005; 4: 17471754.

23. Shishodia S, Aggarwal BB. Guggulsterone inhibits NF-kB and IkBa kinase activation, suppresses expression of anti-apoptotic gene products, and enhances apoptosis. J Biol Chem 2004; 279: 47148-58.

24. Burris TP, Montrose C, Houck KA, Osborne HE, Bocchinfuso WP, Yaden BC, et al. The hypolipidemic natural product guggulsterone is a promiscuous steroid receptor ligand. Mol Pharmacol 2005; 67: 948-954.

25. Lee YR, Lee JH, Noh EM, Kim EK, Song MY, Jung WS, et al. Guggulsterone blocks IL-1 beta-mediated inflammatory responses by suppressing NF-kappaB activation in fibroblast-like synoviocytes. Life Sci 2008; 82: 1203-1209.

26. Van der Heijden PJ, Stok W. Improved procedure for the isolation of functionally active lymphoid cells from the murine intestine. J Immunol Methods 1987; 103: 161-167.

27. Nicoletti I, Migliorati G, Pagliacci MC, Grignani F, Riccardi C. A rapid and simple method for measuring thymocyte apoptosis by propidium iodide staining and flow cytometry. J Immunol Methods 1991; 139: 271-279.

28. Elson CO, Beagley KW, Sharmanov AT, Fujihashi K, Kiyono H, Tennyson GS, et al. Hapten-induced model of murine inflammatory bowel disease: mucosa immune responses and protection by tolerance. J Immunol 1996; 157: 21742185.

29. Neurath MF, Fuss I, Kelsall BL, Stüber E, Strober W. Antibodies to interleukin 12 abrogate established experimental colitis in mice. J Exp Med 1995; 182: 1281-1290. 
30. Neurath MF, Pettersson S, Meyer zum Büschenfelde KH, Strober W. Local administration of antisense phosphorothioate oligonucleotides to the p65 subunit of NF-kappa B abrogates established experimental colitis in mice. Nat Med 1996; 2:998-1004.

31. Wirtz S, Neufert C, Weigmann B, Neurath MF. Chemically induced mouse models of intestinal inflammation. Nat Protoc 2007; 2: 541-546.

32. Boirivant M, Fuss IJ, Chu A, Strober W. Oxazolone colitis: a murine model of T helper cell type 2 colitis treatable with antibodies to interleukin 4. J Exp Med 1998; 188:1929-1939.

33. Heller F, Fuss IJ, Nieuwenhuis EE, Blumberg RS, Strober W. Oxazolone colitis, a Th2 colitis model resembling ulcerative colitis, is mediated by IL-13-producing NK-T cells. Immunity 2002; 17: 629-638.

34. Fiorucci S, Mencarelli A, Palazzetti B, Sprague AG, Distrutti E, Morelli A, et al. Importance of innate immunity and collagen binding integrin alphalbetal in TNBS-induced colitis. Immunity 2002; 17: 769-780.

35. Kane LP, Lin J, Weiss A. It's all Rel-ative: NF-KB and CD28 costimulation of Tcell activation. Trends Immunol 2002; 23: 413-420.

36. Dong C, Davis RJ, Flavell RA. MAP kinases in the immune response. Annu Rev Immunol 2002; 20:55-72.

37.Kane LP, Weiss A. The Pl-3 kinase/Akt pathway and T cell activation: pleiotropic pathways downstream of PIP3. Immunol Rev 2003; 192: 7-20.

38. Shishodia S, Harikumar KB, Dass S, Ramawat KG, Aggarwal BB. The guggul for chronic diseases: ancient medicine, modern targets. Anticancer Res 2008; 28: 3647-3664.

39. Cheon JH, Kim JS, Kim JM, Kim N, Jung HC and Song IS, Plant sterol guggulsterone inhibits nuclear factor-kappaB signaling in intestinal epithelial cells by blocking IkappaB kinase and ameliorates acute murine colitis. Inflamm Bowel Dis. 2006; 12:1152-1161.

40. Dieleman LA, Ridwan BU, Tennyson GS, Beagley KW , Bucy RP and Elson CO. Dextran sulfate sodium-induced colitis occurs in severe combined immunodeficient mice. Gastroenterology 1994; 107:1643-1652. 
41. Singh SV, Choi S, Zeng Y, Hahm ER and Xiao D. Guggulsterone-induced apoptosis in human prostate cancer cells is caused by reactive oxygen intermediate dependent activation of c-Jun NH2-terminal kinase. Cancer Res. 2007; 67: 7439-7449.

42. Shishodia S, Sethi G, Ahn KS and Aggarwal BB. Guggulsterone inhibits tumor cell proliferation, induces S-phase arrest, and promotes apoptosis through activation of c-Jun $\mathrm{N}$-terminal kinase, suppression of Akt pathway, and downregulation of antiapoptotic gene products. Biochem Pharmacol. 2007; 74:118-30

43.Xiao D and Singh SV. z-Guggulsterone, a constituent of Ayurvedic medicinal plant Commiphora mukul, inhibits angiogenesis in vitro and in vivo. Mol Cancer Ther. 2008; 7:171-80.

44.Xia Z, Dickens M, Raingeaud J, Davis RJ and M.E. Greenberg, Opposing effects of ERK and JNK-p38 MAP kinases on apoptosis. Science 1995; 270:1326-1331.

45. Faris M, Kokot N, Latinis K, Kasibhatla S, Green DR, Koretzky GA and. Nel A. The C-Jun $\mathrm{N}$-terminal kinase cascade plays a role in stress-induced apoptosis in Jurkat cells by up-regulating Fas ligand expression. J Immunol. 1998; 160:134-144.

46. Tobiume K, Matsuzawa A, Takahashi T, Nishitoh H, Morita K, Takeda K and et al. ASK 1 is required for sustained activations of JNK/P38 MAP kinases and apoptosis, EMBO Rep. 2001; 2: 222-228.

47. Tournier C, Hess P, Yang DD, XU J, Turner TK, Nimnual A, Bar-Sagi D and Jones $\mathrm{SN}$. Requirement of JNK for stress-induced activation of the cytochrome cmediated death pathway, Science 2000; 288: 870-4.

48. Green DR. Overview: apoptotic signaling pathways in immune system, Immunol. Rev. 2003; 193: 5-9.

49. Frauwirth KA, Riley JL, Harris MH, Parry RV, Rathmell JC, Plas DR, Elstrom RL, June $\mathrm{CH}$ and Thompson $\mathrm{CB}$. The CD28 signaling pathway regulates glucose metabolism. Immunity 2002; 16:769-777.

50. Kane LP, Shapiro VS, Stokoe D and Weiss A. Induction of NF-kB by the Akt/PKB kinase. Curr Biol 1999; 9:601-604. 
51.Kane LP, Andres PG, Howland KC, Abbas AK and Weiss A. Akt provides the CD28 co-stimulatory signal for upregulation of IL-2 and IFN- $Y$ ? but not Th2 cytokines. Nat Immunol. 2001; 2: 37-44.

52. Ahn KS, Sethi G, Sung B, Goel A, Ralhan R and Aggarwal BB. Guggulsterone, a farnesoid $X$ receptor antagonist, inhibits constitutive and inducible STAT3 activation through induction of a protein tyrosine phosphatase SHP-1. Cancer Res. 2008; 68:4406-4415.

53. Verma N, Singh SK and Gupta RC. Pharmacokinetics of guggulsterone after intravenous and oral administration in rats. Pharm Pharmacol Comm. 1999; 5: 349.

54. Fiorucci S, Antonelli E, Distrutti E, Del Soldato P, Flower RJ, Clark MJ, Morelli A, Perretti M, Ignarro LJ. NCX-1015, a nitric-oxide derivative of prednisolone, enhances regulatory $T$ cells in the lamina propria and protects against 2,4,6trinitrobenzene sulfonic acid-induced colitis in mice. Proc Natl Acad Sci U S A. 2002; 99:15770-5.

55. Paul-Clark M, Del Soldato P, Fiorucci S, Flower RJ, Perretti M. 21-NOprednisolone is a novel nitric oxide-releasing derivative of prednisolone with enhanced anti-inflammatory properties. Br J Pharmacol. 2000; 131:1345-54.

56. Ulbricht C, Basch E, Szapary P, Hammerness $P$, Axentsev S, Boon H, Kroll D, Garraway L, Vora M, Woods J; Natural Standard Research Collaboration. Guggul for hyperlipidemia: a review by the Natural Standard Research Collaboration Complement Ther Med. 2005; 13: 279-90. 


\section{Figure Legends:}

Figure 1: Early administration of E-GS $(30 \mathrm{mg} / \mathrm{kg})$ protects against the development of TNBS-induced colitis in mice. Colitis was induced by intrarectal instillation of $1 \mathrm{mg}$ of TNBS per mouse, and animals were killed 5 days after TNBS administration. GSstereoisomers were administered intraperitoneally daily for 5 days, starting at the same time of intrarectal instillation of TNBS. (A and B) The severity of TNBS-induced inflammation (wasting disease and fecal score) is reduced by E-GS administration. Data represent the mean \pm SE of 8-10 mice per group. \#P<0.05 vs TNBS. (C and D) E-GS protects against local signs of inflammation and protects against the increase of macroscopic- microscopic-score induced by intrarectal instillation of TNBS. Data represent the mean \pm SE of 8-10 mice per group. \#P $<.05$ vs TNBS plus vehicle group. (E) Histologic analysis of colon samples obtained from mice sacrificed 5 days after TNBS. Original magnification 10x, H\&E staining. TNBS administration causes colon wall thickening and massive inflammatory infiltration in the lamina propria. Administering TNBS mice with E-GS (30 mg/kg) attenuates colon thickening and inflammatory infiltration of the mucosa and submucosa. (F) Structure of GS E and Z. (G). Reverse-transcription polymerase chain reaction (RT-PCR) analysis of expression of inflammatory mediators in colons obtained 5 days after administration of TNBS alone or in combination with GS-stereisomers. Data represent the mean \pm SE of 5 mice per group. $\# P<0.05$ vs TNBS plus vehicle group.

Figure 2: Early administration of E-GS protects against the development of oxazolone-induced colitis in mice. Colitis was induced by intrarectal instillation of $1.5 \mathrm{mg}$ of oxazolone and animals were sacrificed 5 days later. GS-stereoisomers were administered intraperitoneally at ethe dose of $30 \mathrm{mg} / \mathrm{kg} /$ day for 5 days, starting at the same time of intrarectal instillation of oxazolone. (A and B) E-GS protects against development of wasting disease and fecal score induced by oxazolone. (C and D) E-GS and Z-GS administration attenuates the severity of oxazolone-induced inflammation (macroscopic- microscopic- score). Data 
represent the mean \pm SE of 8-10 mice per group. $\# P<0.05$ vs oxazolone. (E) Histological analysis (original magnification 10x, H\&E staining) of the colon harvested 5 days after oxazolone administration with or without treatment with GS-stereoisomers. Oxazolone administration alone causes a massive inflammatory infiltration in the subepithelial layer and epithelial cell necrosis. These effects were attenuated by administration of GS stereoisomers (F) Administration of GSstereoisomers $(30 \mathrm{mg} / \mathrm{kg}$ ) attenuates increases of inflammatory mediators caused by oxazolone. Colon specimens were harvested from mice sacrificed 5 days after oxazolone administration. Data represent the mean \pm SE of 5 mice per group. \#P< 0.05 vs Oxazolone plus vehicle group.

Figure 3: Development of TNBS-induced colitis does not require $T$ and $B$ lymphocytes. SCID mice were treated with $1 \mathrm{mg} / \mathrm{mouse}$ of TNBS alone or in combination with E-GS (30 mg/kg) for 5 days. (A, B and C) E-GS $30 \mathrm{mg} / \mathrm{kg}$ failed to protect against development of wasting disease and diarrhea and was of limited efficacy on colon macroscopic injury induced by intrarectal instillation of TNBS. Data represent the mean \pm SE of 8-10 mice per group.

Figure 4: Effects of GS-stereoisomers on CD4+ lamina propria cells obtained from mice administered 5 TNBS or oxazolone .(A, B and C) Th 1 profile: production of IL-2 and INFY and proliferation of lamina propria CD4+ cells obtained from mice administered TNBS and stimulated ex vivo with CD3-CD28 mAbs alone or in combination with GS-stereoisomers (10 MM). (D, E and F) Th2 profile: production of IL-2 and IL-4 and proliferation of lamina propria CD4+ cells obtained from mice administered oxazolone and stimulated ex vivo with CD3-CD28 mAbs alone or in

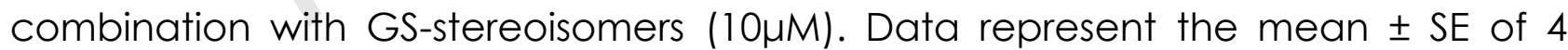
experiments. ${ }^{*} P<0.05$ vs CD3-CD28 group; \#P<0.05 vs CD3-CD28 plus Z-GS 10 $4 \mathrm{M}$ group.

Figure 5: Effect of GS stereoisomers on CD3-CD28 induced phosphorylation of P38MAPK, JNKs and AKT lamina propria CD4+ cells obtained from colon mice treated with TNBS. GS (100-10 $\mu \mathrm{M})$ modified cell signalling transduction pathway, 
at high dose induced hyper-phosphorylation of p38MAPK and JNKs and inhibited AKT activation, whereas E-GS at $10 \mu \mathrm{M}$ maintained its ability to prevent AKT phosphorilation. (A) p(Thr183/Tyr185)JNKs levels. (B) p(Tyr180/182)p38MAPK levels. (C) $p$ (ser473)AKT levels. Data represent the mean \pm SE of 3 experiments. ${ }^{*} P<0.05$ vs CD3-CD28 group; \#P<0.05 vs CD3-CD28 plus Z-GS $100 \mu \mathrm{M}$ group.

Figure 6: GS-stereoisomers induce apoptosis of lamina propria-derived CD4+ cells. (A)Time course of apoptosis, lamina propria CD4+ T cells were stained with propidium iodide, and analyzed by flow cytometer. Data represent the mean \pm SE of 6 experiments (B) Time course of ROI production, lamina propria CD4+ T cells were stained with H2DCFDA, and analyzed by flow cytometer. Data represent the mean \pm SE of 6 experiments (C) Time course membrane potential $\left(\Delta \Psi_{m}\right)$, lamina propria CD4+ T cells were stained with the fluorescent dye JC-1, and analyzed by flow cytometer. Data represent the mean \pm SE of 6 experiments (D) Release of CytC by lamina propria CD4+ T cells after 12 hour of incubation with CD3-CD28 alone or in combination with GS-stereoisomers. Data represent the mean \pm SE of 6

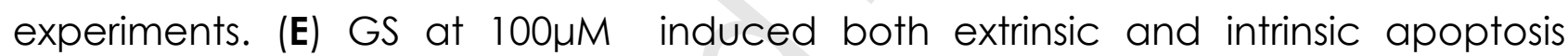
pathway but E-GS was more efficacious to induce mitochondrial damage as demonstrated by major caspase-9 activation and subsequently a robust induction of caspase- 3 compared to Z-GS. Data represent the mean \pm SE of 4 experiments (F) Induction of apoptosis by GS-stereoisomers is mediated by activation of JNKs. Pre-treatment of lamina propria CD4+ cells with the JNKs inhibitor, SP600125, attenuates apoptosis induced by GSs. Data represent the mean \pm SE of 6 experiments. ${ }^{*} P<0.05$ vs CD3-CD28 alone; $\# P<0.05$ vs GS stereoisomers.

Figure 7. Early administration of E-GS $(30 \mathrm{mg} / \mathrm{kg})$ and prednisolone $(10 \mathrm{mg} / \mathrm{kg})$ protects against $t$ development of TNBS-induced colitis in mice. Colitis was induced by intrarectal instillation of $1 \mathrm{mg}$ of TNBS per mouse, and animals were killed 5 days after TNBS administration. E-GS and predinisolone were administered intraperitoneally daily for 5 days, starting at the same time of intrarectal instillation of TNBS. (A and B) The severity of TNBS-induced inflammation (wasting disease and fecal score) was reduced by pharmacological treatments. Data represent the 
mean \pm SE of 8-10 mice per group. \#P $<0.05$ vs TNBS. (C and D) E-GS $(30 \mathrm{mg} / \mathrm{kg}$ ) and prednisolone $(10 \mathrm{mg} / \mathrm{kg})$ protects against local signs of inflammation and protects against the increase of macroscopic-score and myeloperossidase activity (MPO) induced by intrarectal instillation of TNBS. Data represent the mean \pm SE of 8-10 mice per group. \#P $<0.05$ vs TNBS plus vehicle group. 


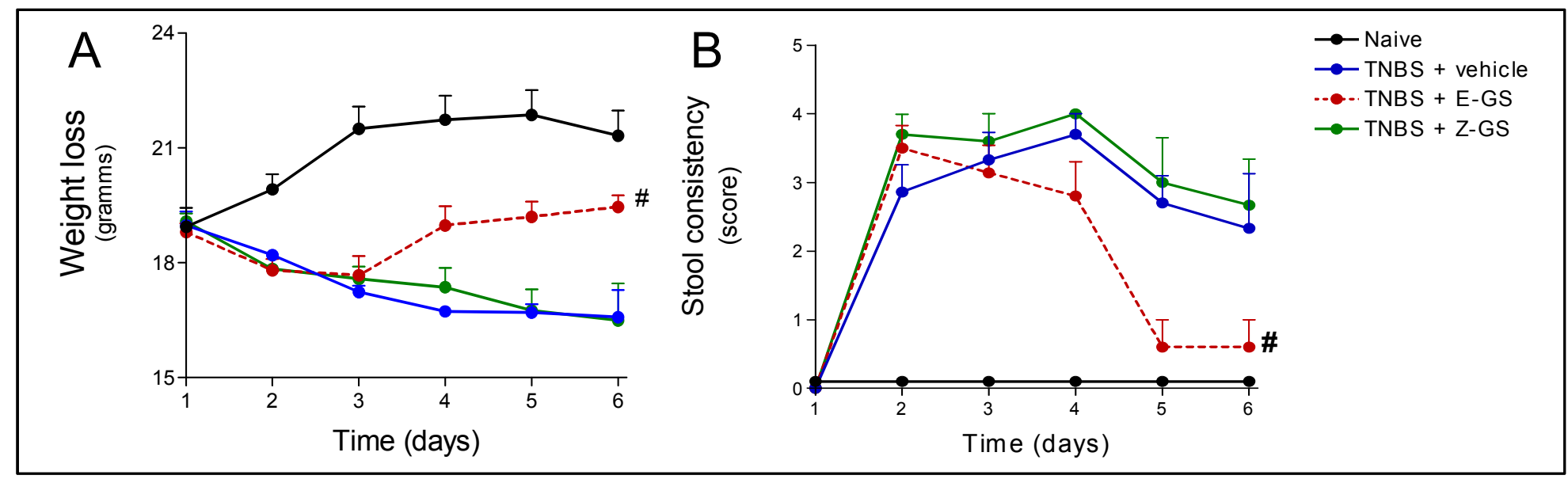

C $\square_{\text {Absent }} \square_{\text {Mld }} \square_{\text {Mbderate }} \square_{\text {Severe }} \quad E$
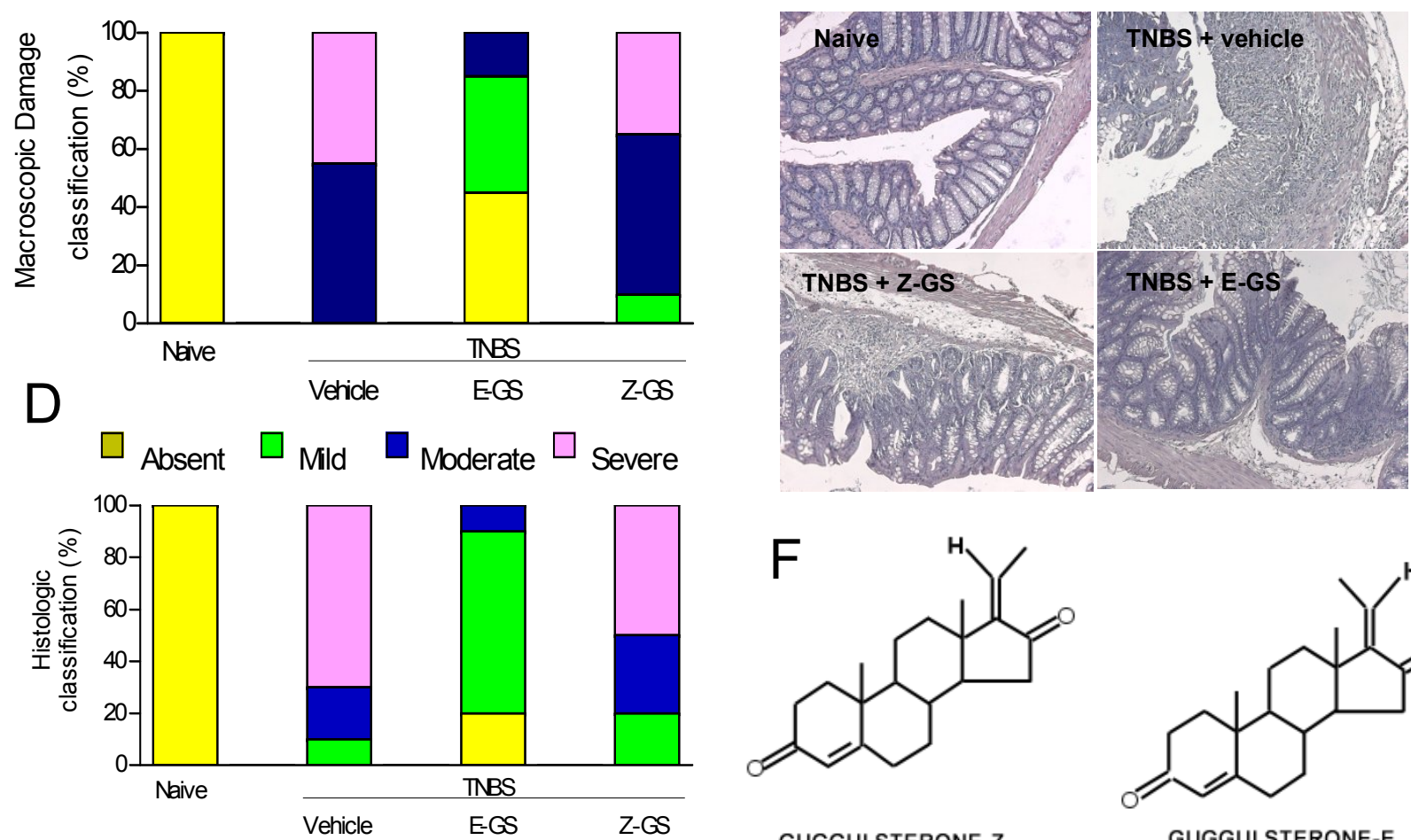

Figure 1
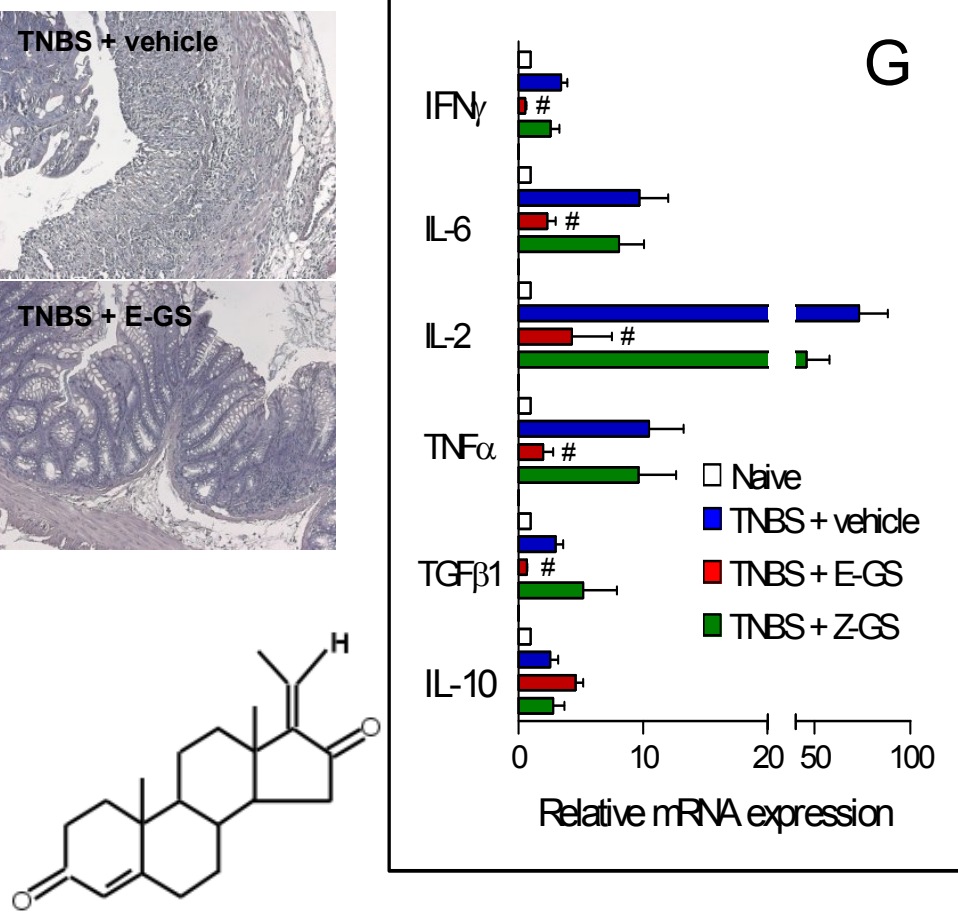

GUGGULSTERONE-Z

GUGGULSTERONE-E 

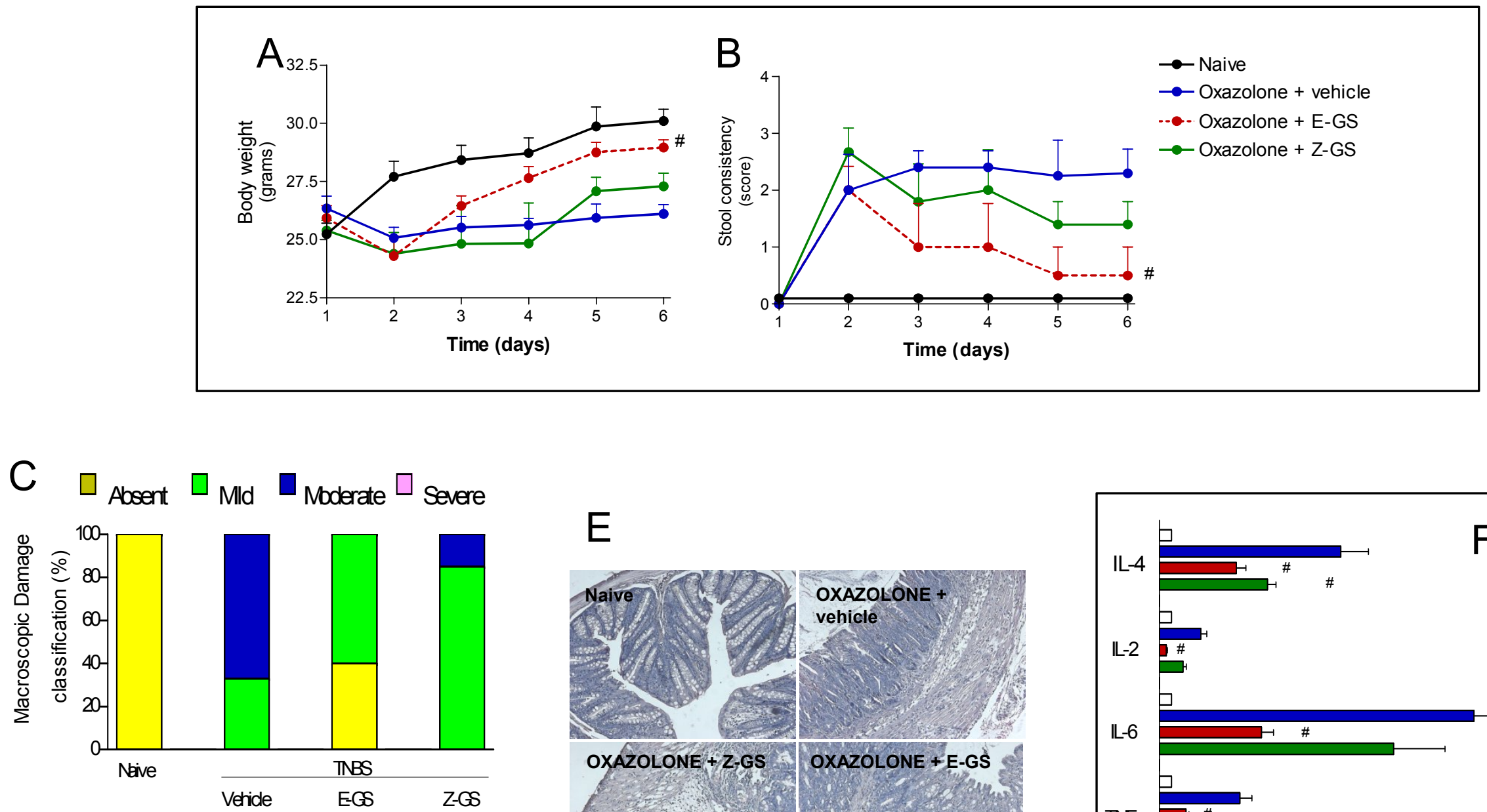

D $\square$ Absent $\square$ Mild $\square$ Moderate $\square$ Severe



E



Figure 2



Relative mRNA expression 

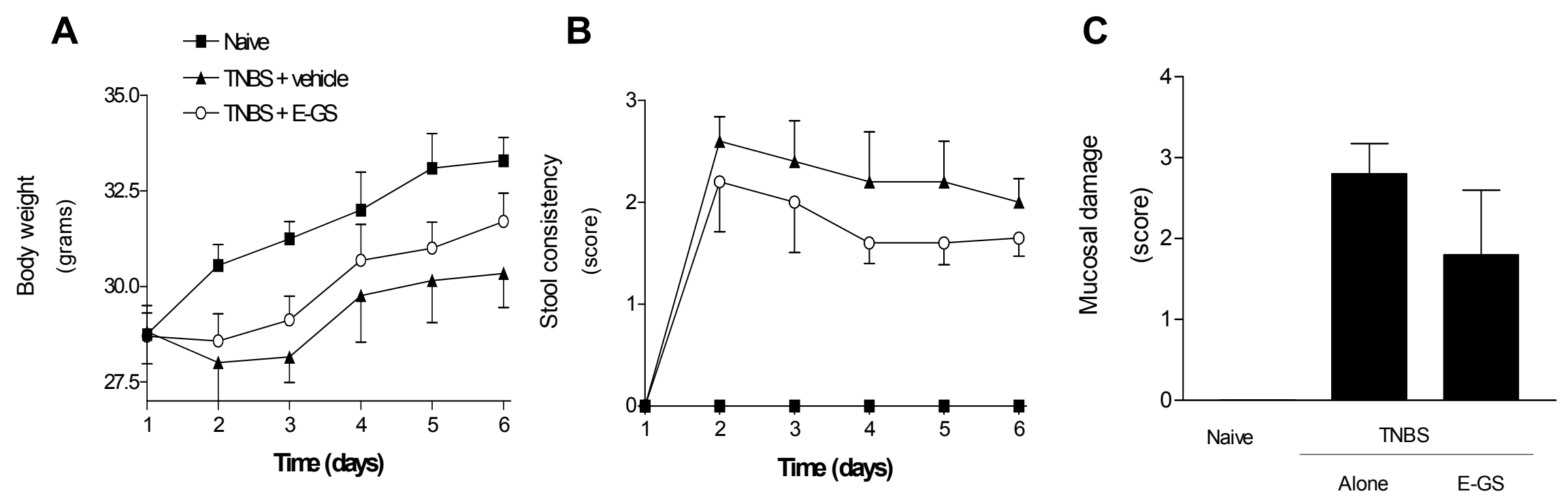

Figure 3 
CD4+/TNBS induced colitis

A

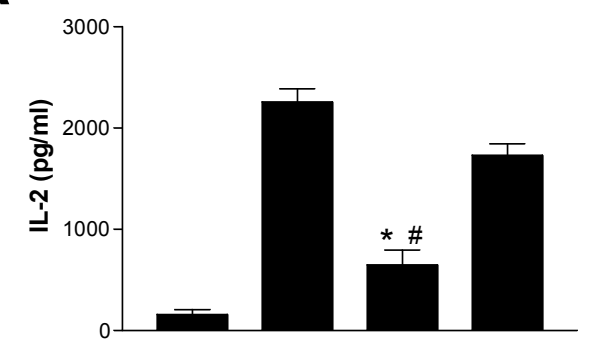

B

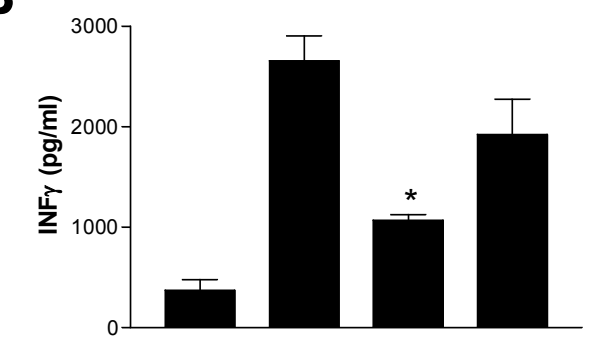

C

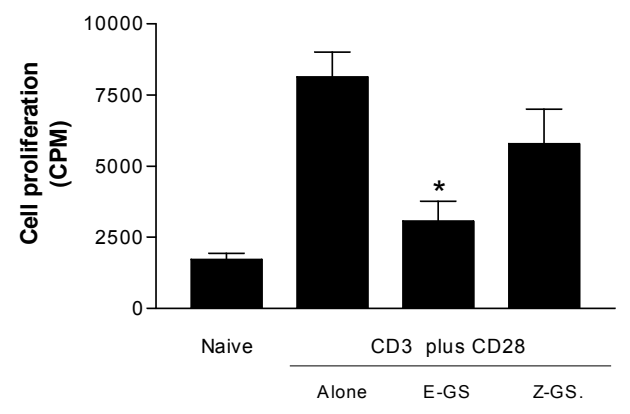

CD4+/ Oxazolone induced colitis

D

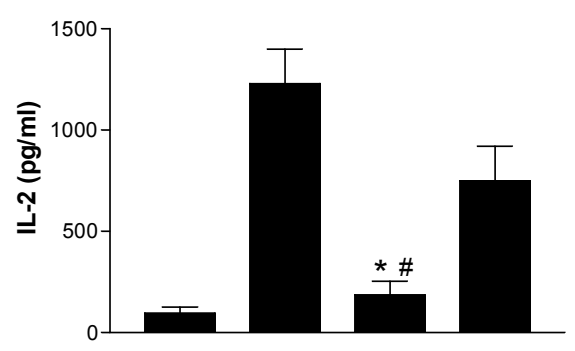

E



$\mathbf{F}$

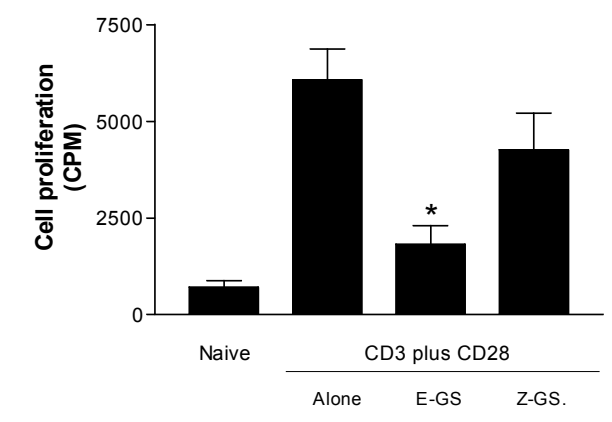

Figure 4 

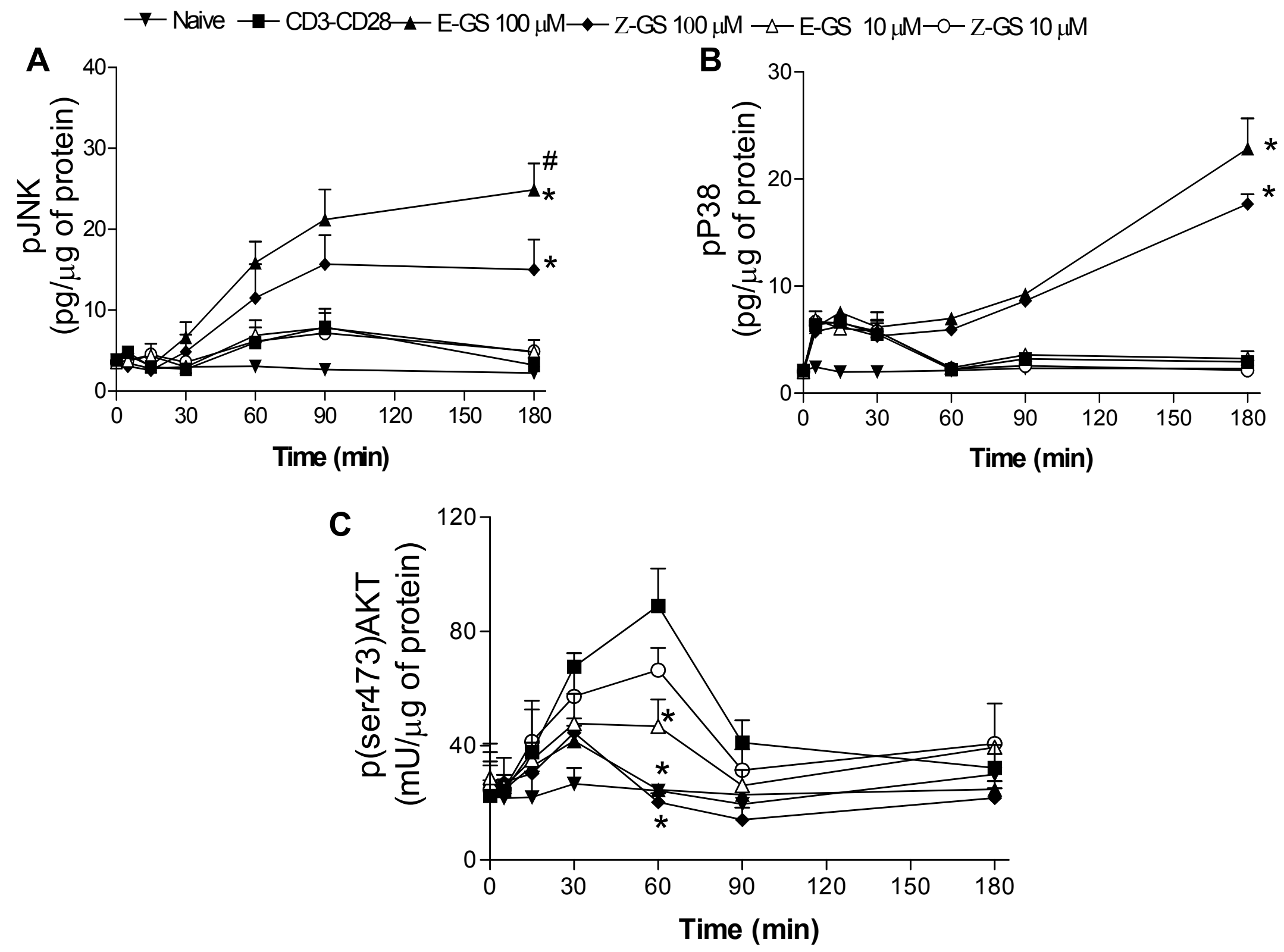

Figure 5 

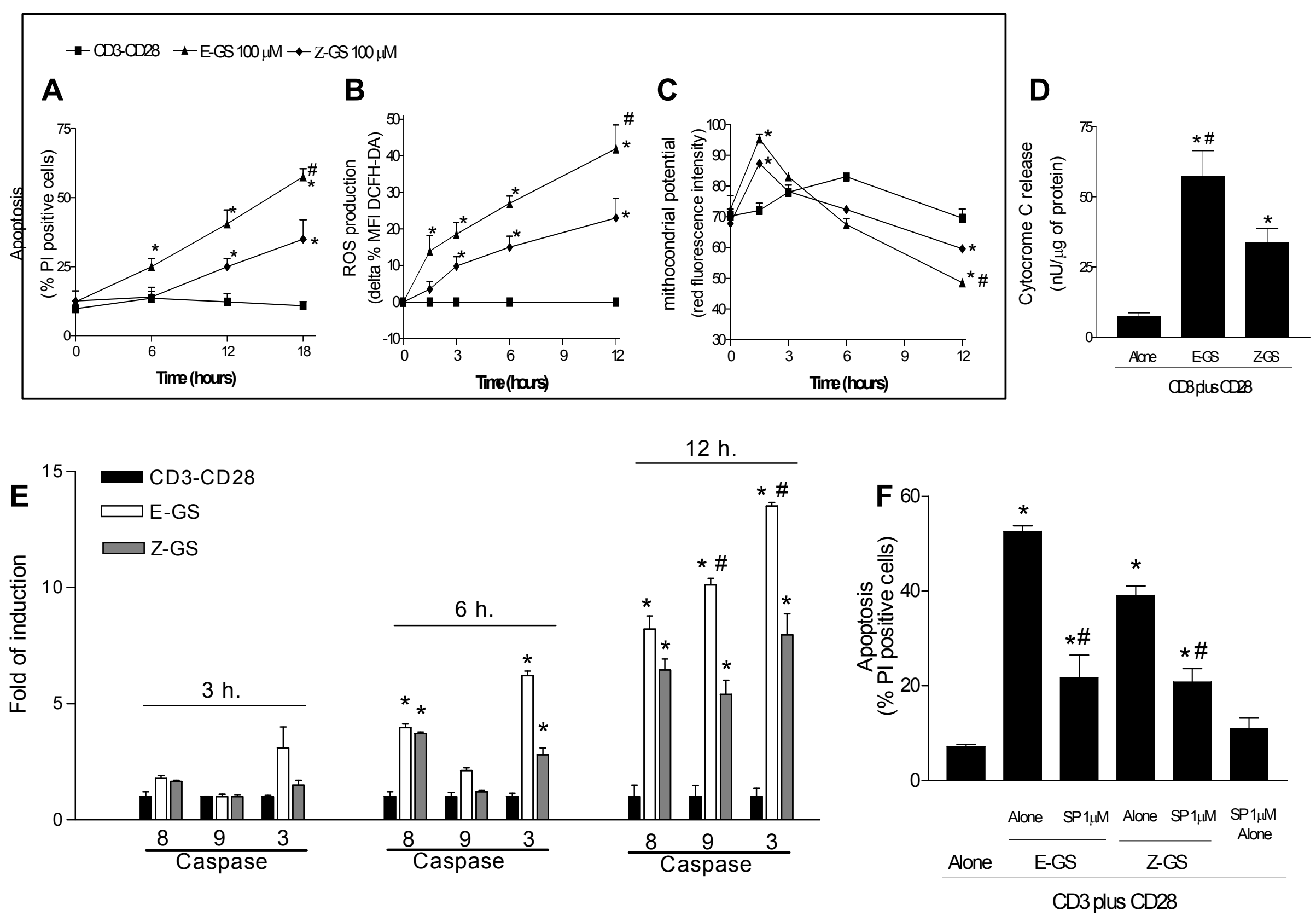

Figure 6 
A.

B.

$\rightarrow$ Naive $\bullet-$ TNBS + Vehicle $\multimap-$ TNBS + Prednisolone 10mg/kg $\bullet-$ TNBS + E-GS 30mg/kg
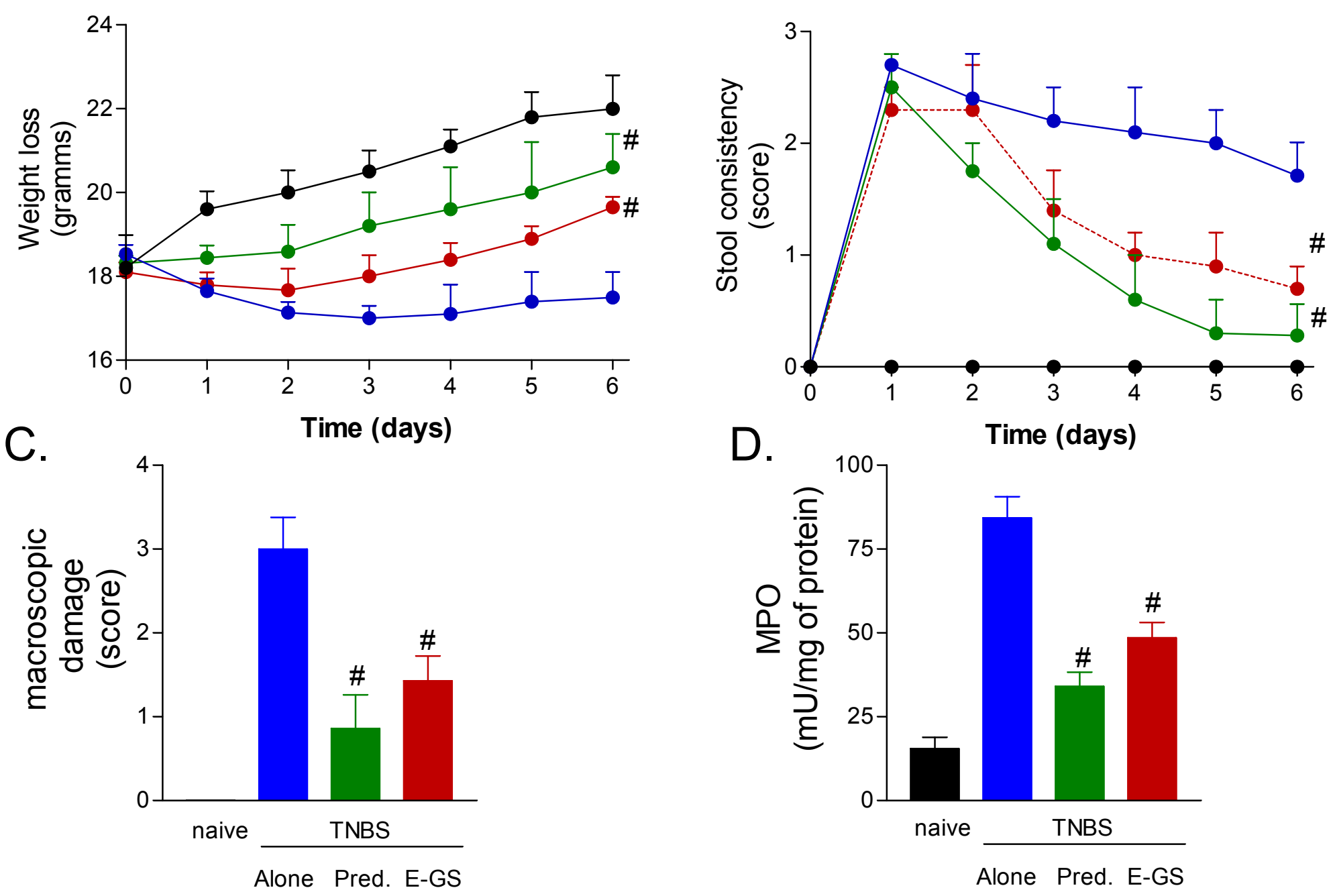

Figure 7 


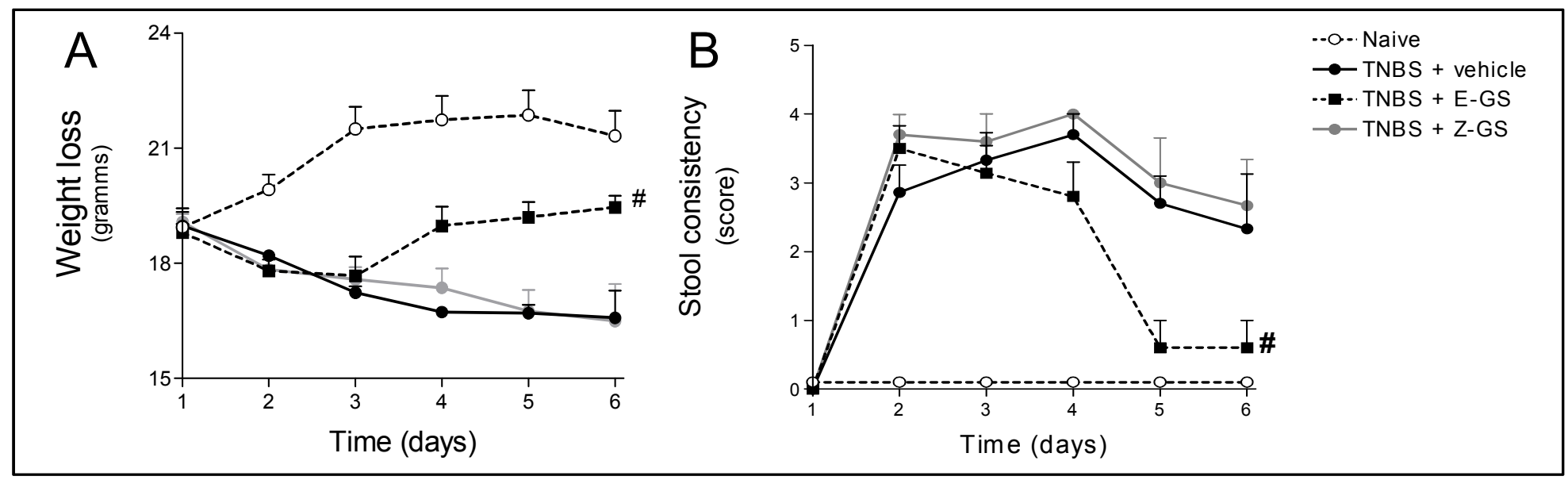

C
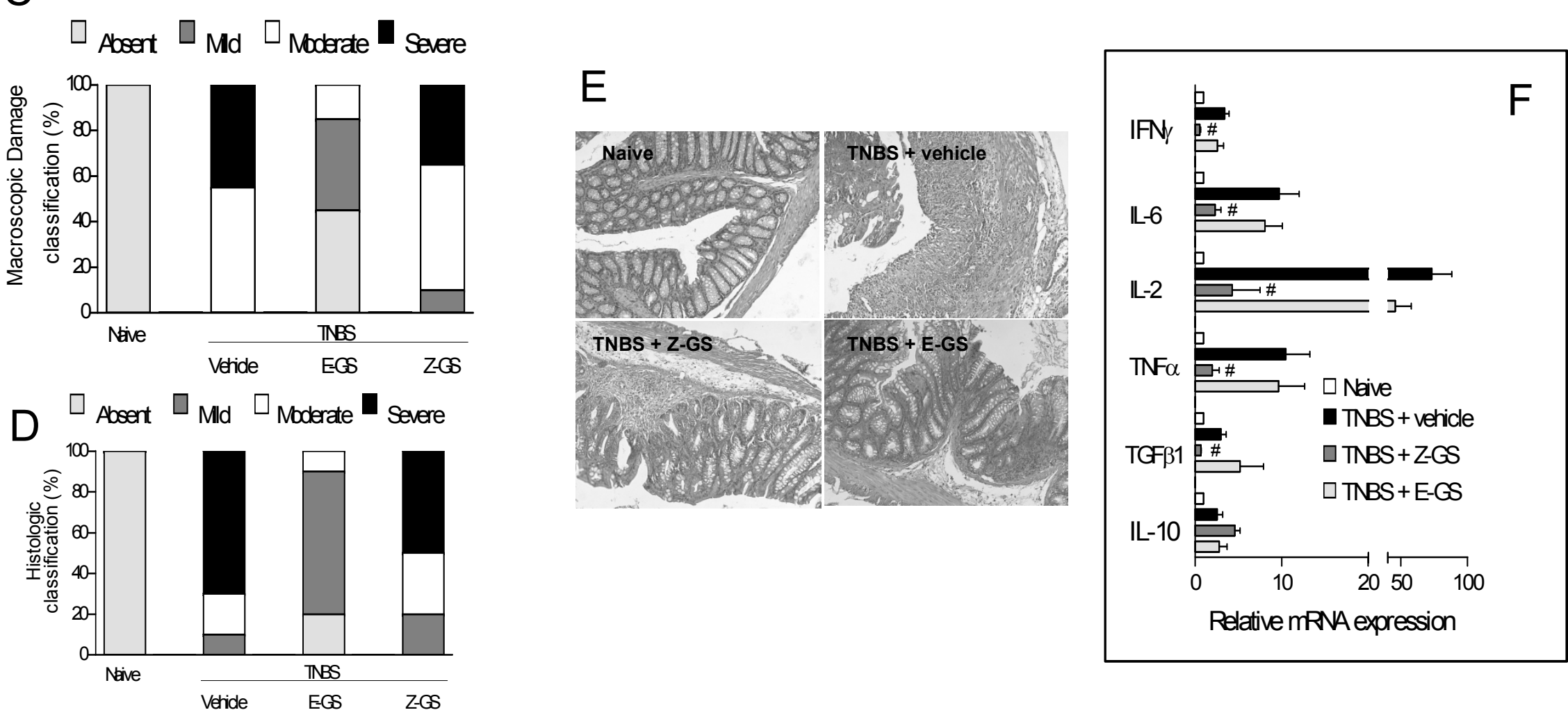

Figure 1 

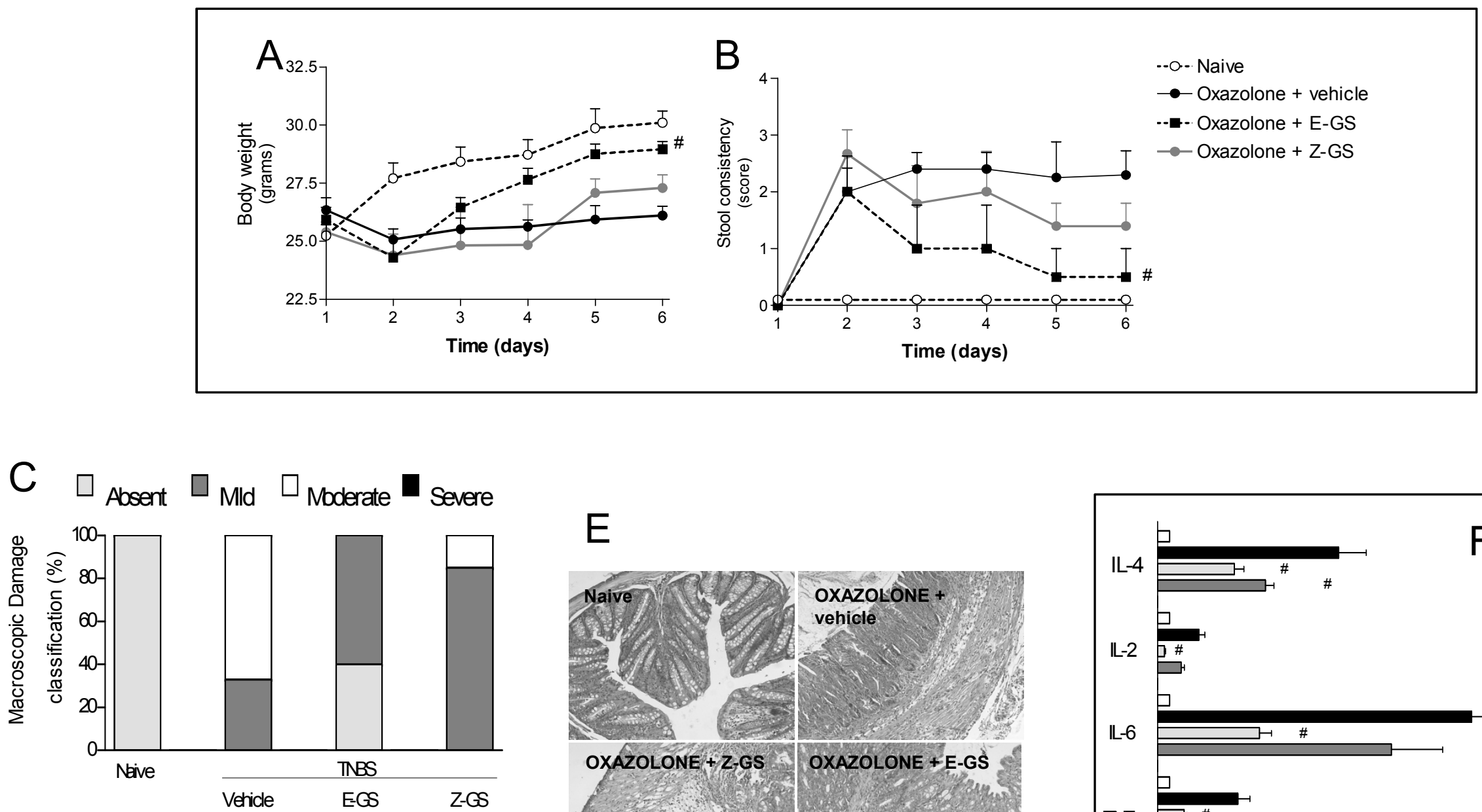

D $\square$ Absent $\square$ Mld $\square$ Mbderate $\square$ Severe

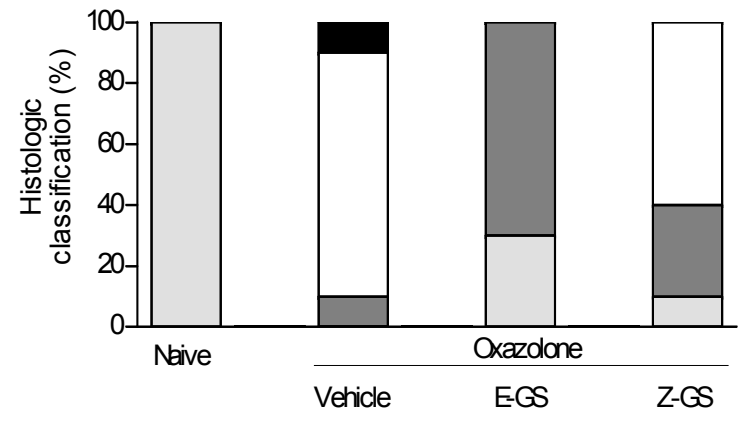

$E$

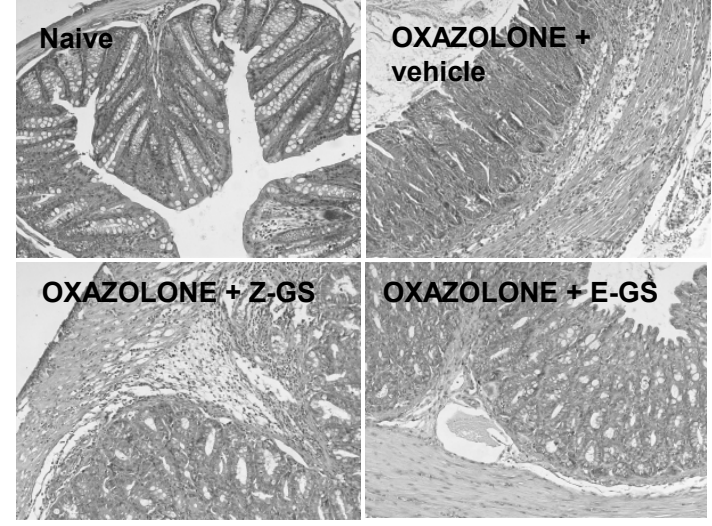

Figure 2

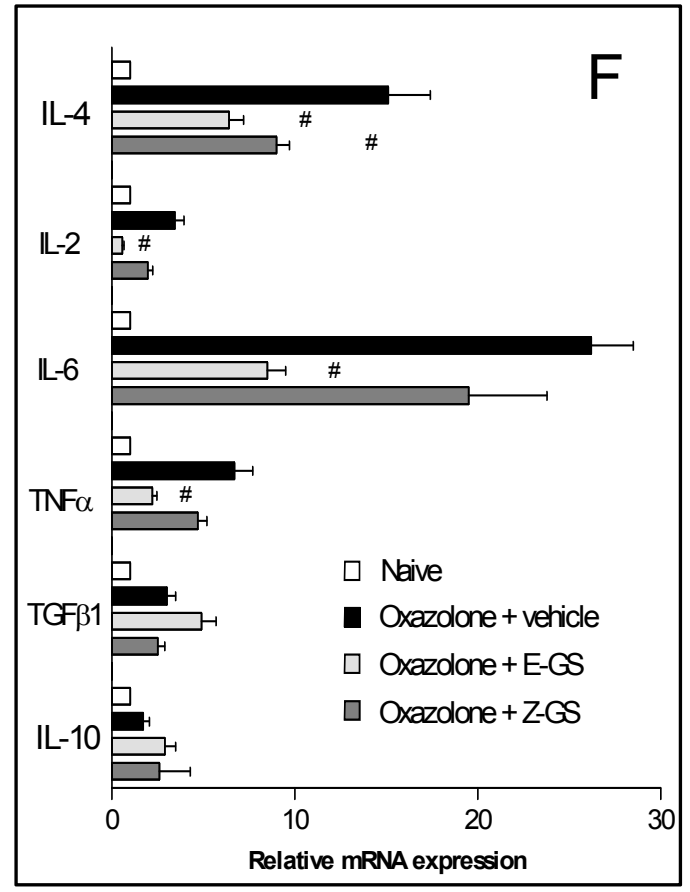

Relative mRNA expression 

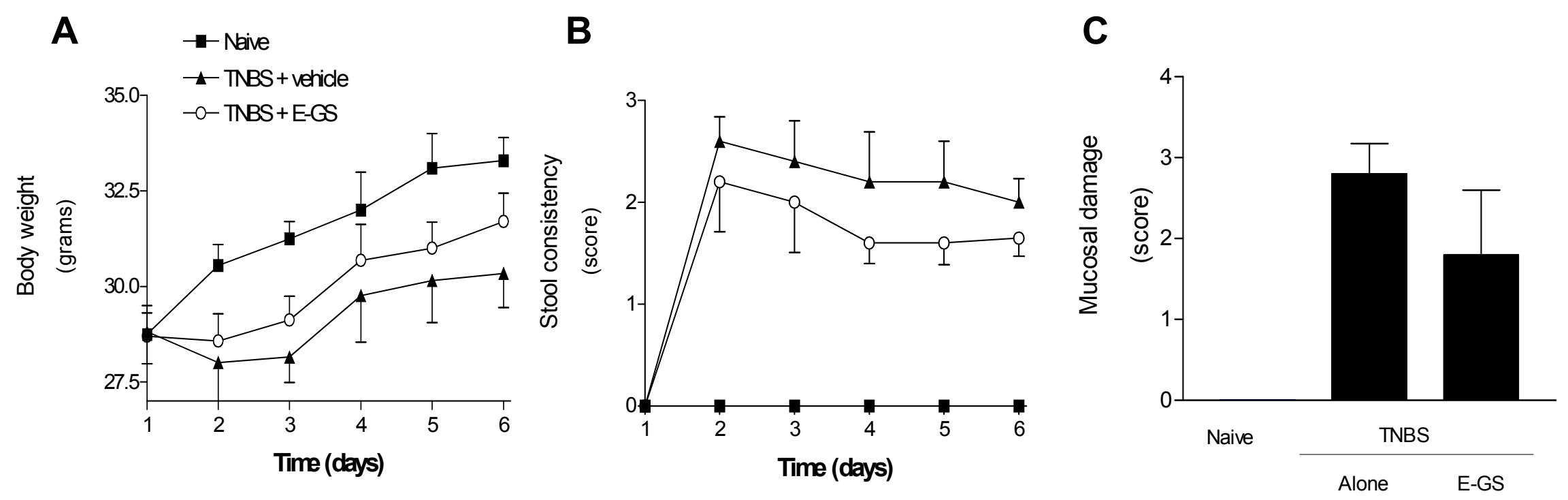

Figure 3 
CD4+/TNBS induced colitis

A

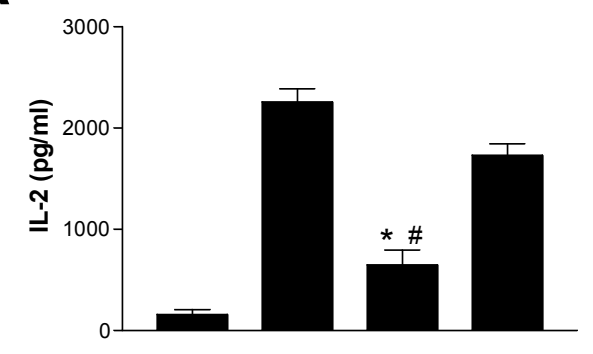

B



C

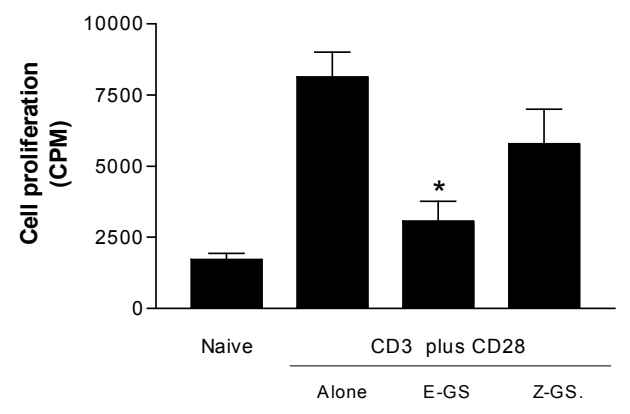

CD4+/ Oxazolone induced colitis

D

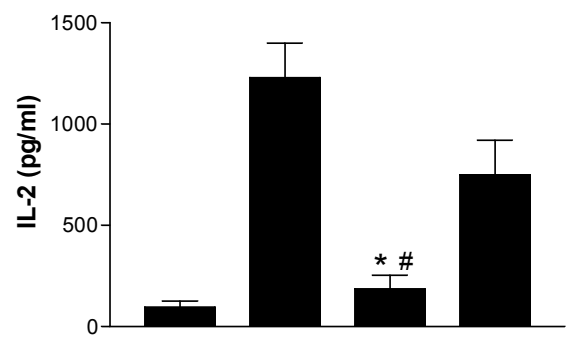

E

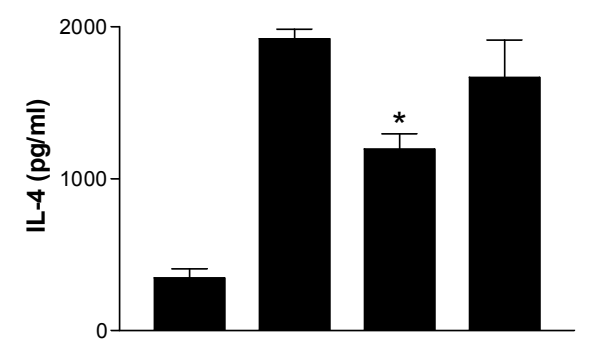

$\mathbf{F}$

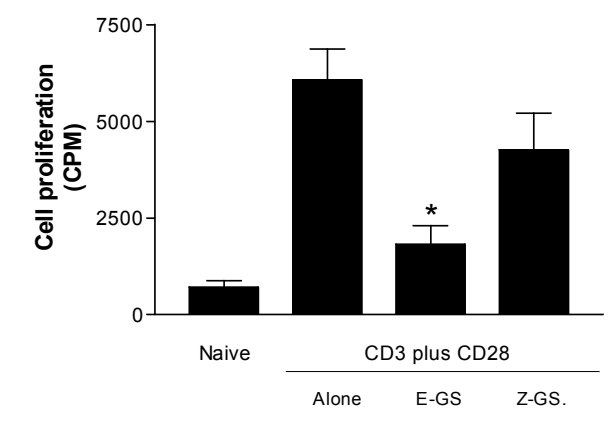

Figure 4 

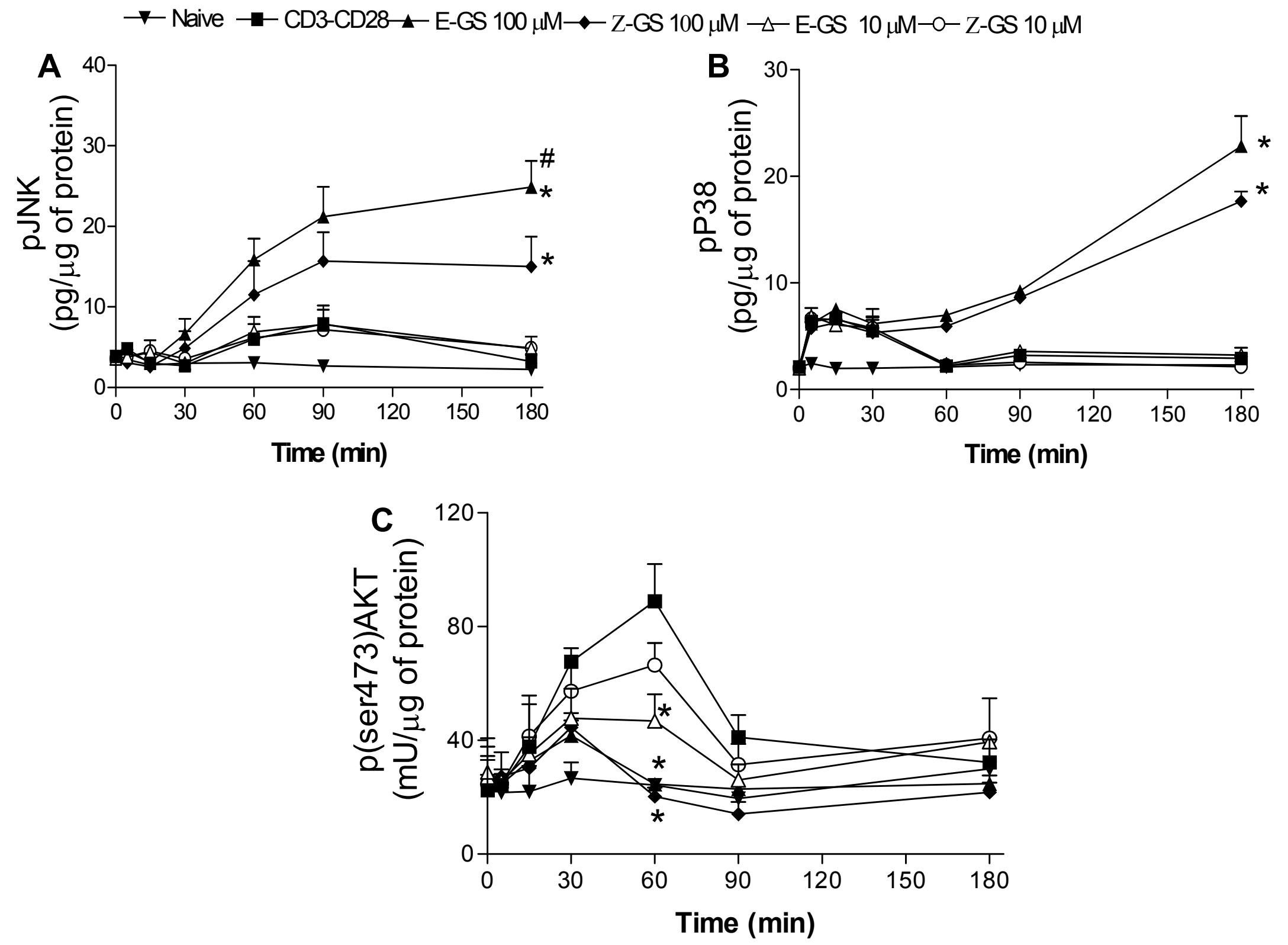

Figure 5 

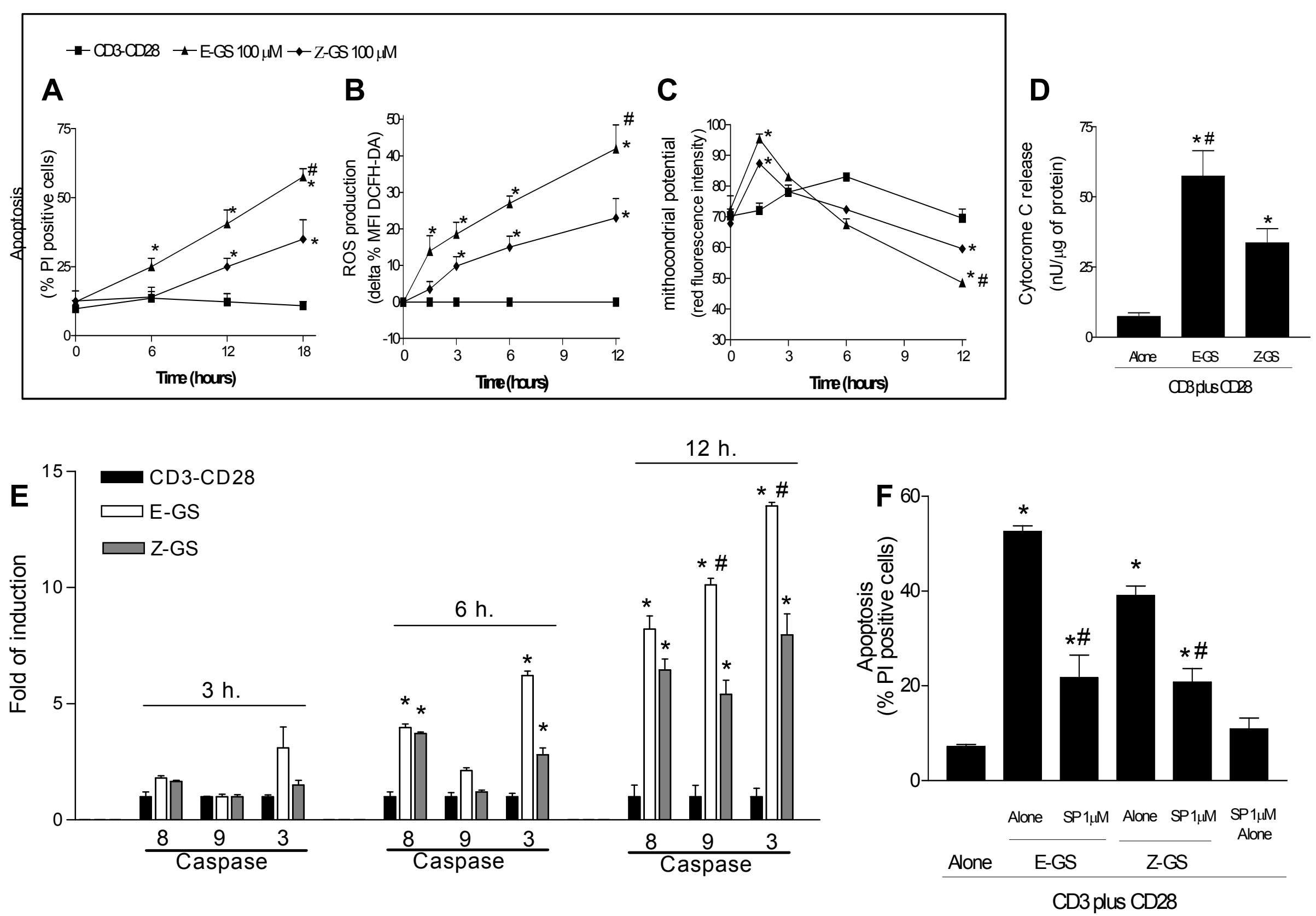

Figure 6 


\section{A}

B

$\because$ - N Naive $\rightarrow-$ TNBS + Vehicle $-\bullet$ TNBS + Prednisolone 10mg/kg $\rightarrow-$ TNBS + E-GS 30mg/kg
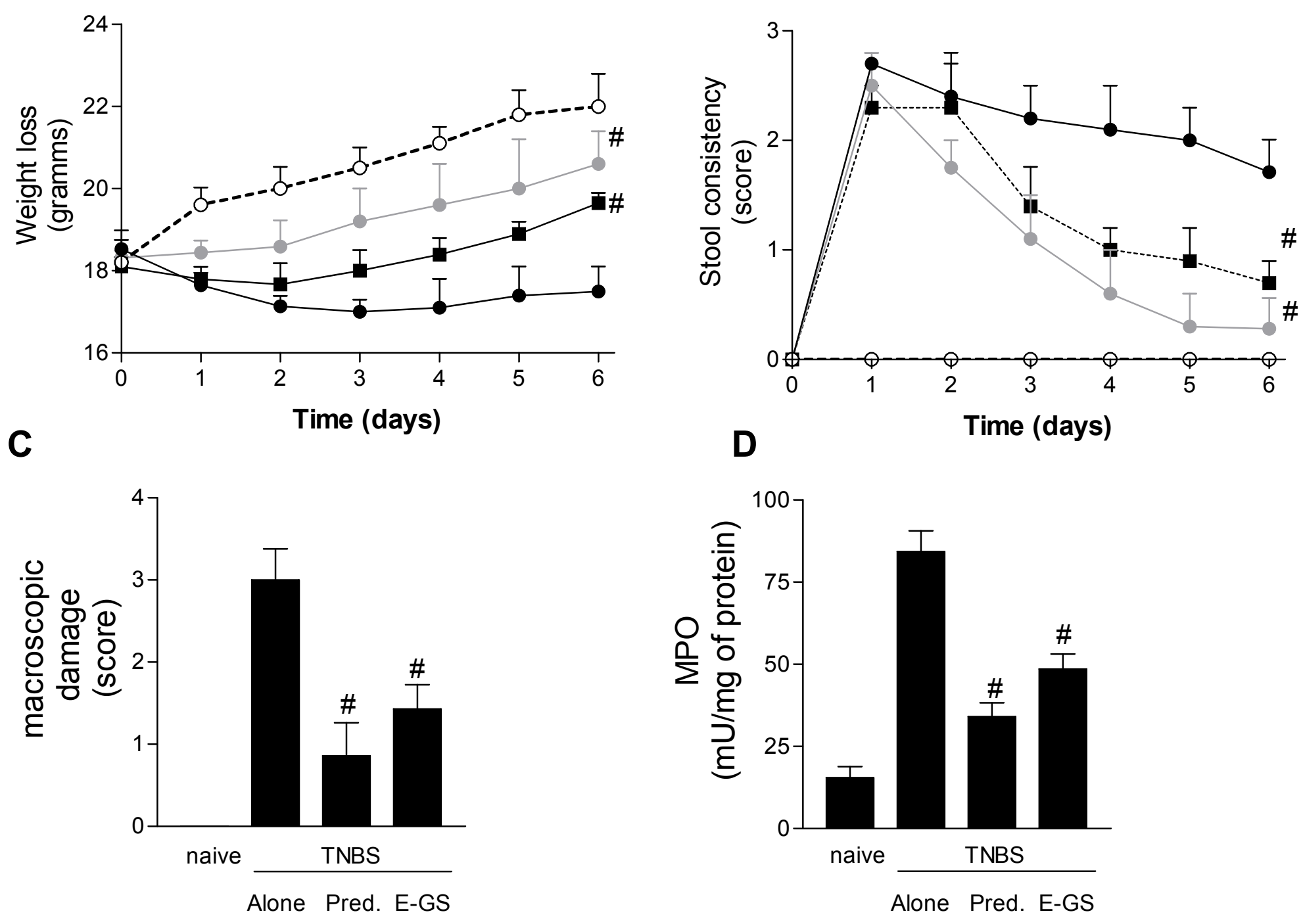

Figure 7 


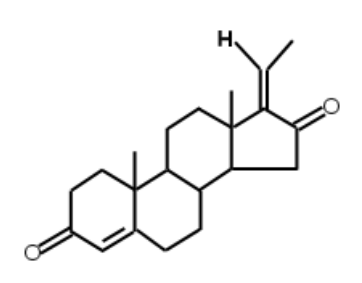

GUGGULSTERONE-Z
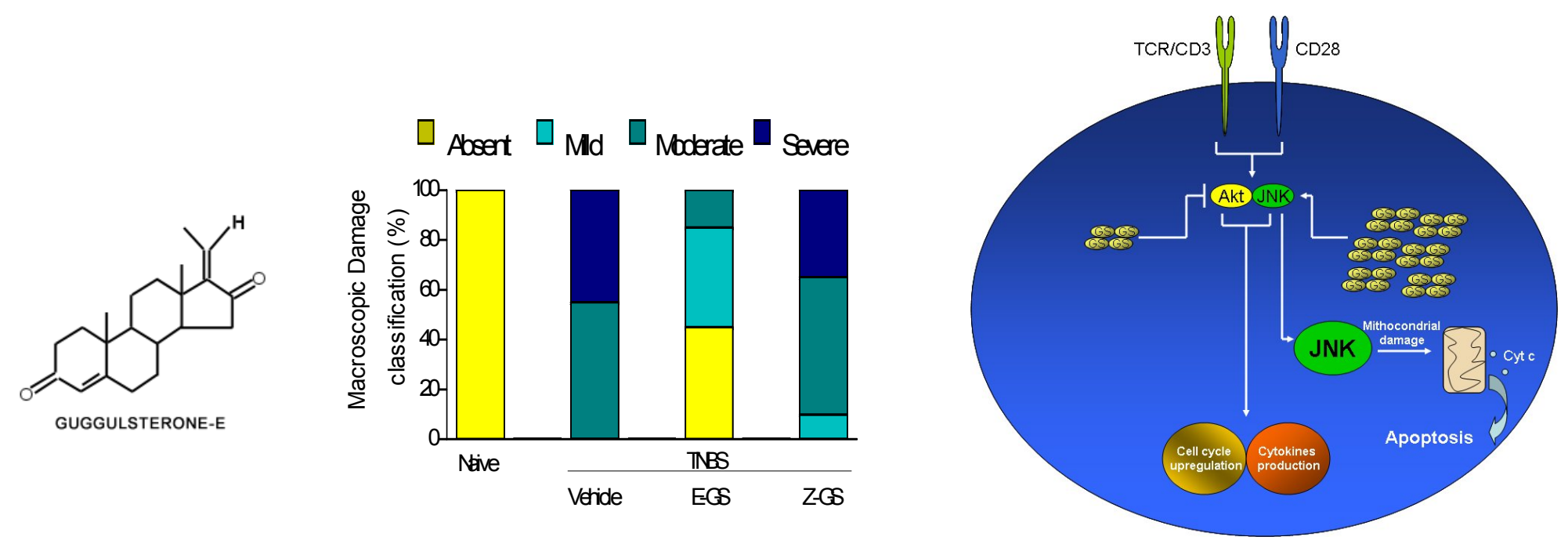

Guggulsterone is a plant sterol that exerts immunomodulatory activities in rodent models of T-cell-induced colitis. Guggulsterone directly modulates intracellular pathways in intestinal CD4+ cells 